\title{
A revised Early Miocene age for the instigation of the Eirik Drift, offshore southern Greenland: Evidence from high-resolution seismic reflection data
}

\author{
Antje Müller-Michaelis*, Gabriele Uenzelmann-Neben, Rüdiger Stein \\ Alfred-Wegner-Institut, Helmholtz-Zentrum für Polar- und Meeresforschung, Am Alten Hafen 26, 27568 Bremerhaven, Germany
}

\section{A R T I C L E I N F O}

\section{Article history:}

Received 8 October 2012

Received in revised form 10 April 2013

Accepted 15 April 2013

Available online 2 May 2013

Communicated by D.J.W. Piper

Keywords:

sediment drift

Labrador Sea

North Atlantic Deep Water (NADW)

ODP Leg 105 Site 646

IODP Expedition Sites U1305-1307

\begin{abstract}
A B S T R A C T
The Eirik Drift lies on the continental slope south of Greenland, where it has been formed under the influence of Northern Component Water (NCW). NCW flow is an essential part of the global Thermohaline Circulation (THC), which is closely connected to the world's climate. Changes in pathways and intensity of NCW flow bear information about modifications of the North Atlantic THC in a changing climate. There is some disagreement about when deep-current controlled sedimentation at the Eirik Drift started. While the onset of drift building was previously dated as early Pliocene or late Miocene in age we suggest that the effect of large-scale current deposition had been initiated by at least 19-17 Ma based on the seismostratigraphic analysis of sedimentary structures identified in a set of high-resolution seismic reflection data. This assumption of an early Miocene onset of NCW flow is supported by regional evidence regarding the breaching of the Greenland-Scotland Ridge, which is documented in several erosional unconformities within the North Atlantic. After the onset of deep-current controlled sedimentation at the Eirik Drift, two major changes in the deep-current system are revealed during the Miocene: At the mid- to late Miocene boundary (12-10 Ma) and at 7.5 Ma.
\end{abstract}

(c) 2013 Elsevier B.V. All rights reserved.

\section{Introduction}

The global Thermohaline Circulation (THC) is closely connected to major changes in Earth's climate (Dickson and Brown, 1994). The surface branch of the THC transports heat and freshwater around the world's oceans and interacts with the overlying atmosphere through surface fluxes (Schmitz, 1996). The formation of deep water in the basins of the northern North Atlantic, Arctic and Antarctic is a mechanism driving the global THC (Dickson and Brown, 1994; Schmitz, 1996). The Eirik Drift, located offshore southern Greenland is built under the influence of the deep-water currents originating as overflows from the Nordic Sea deep-water formation regions (North Atlantic Deep Water (NADW)) (Fig. 1; e.g. Arthur et al., 1989; Hunter et al., 2007a; Wold, 1994). Therefore, the sedimentary structures and packages of the Eirik Drift archive changes in strength and direction of these deep-water currents. As the NADW flow is today's main contributor to the lower branch of the North Atlantic THC, decoding of these deep-water currents yields information about the development of the global THC (Schmitz, 1996).

Even though it is certain that the Eirik Drift was built under the influence of these deep-water currents (e.g. Arthur et al., 1989; Wold, 1994; Hunter et al., 2007a,b), the timing of the onset of development of the Eirik Drift remains ambiguous. Arthur et al. (1989) suggested that the "modern" pattern of deep circulation in the Labrador Sea was established sometime in the late Miocene (8.2-7.5 Ma), but they dated the onset of deep current-controlled deposition at $4.5 \mathrm{Ma}$. By

\footnotetext{
* Corresponding author. Tel.: +49 4714831 1948; fax: + 4947148311271. E-mail address: Antje.Mueller-Michaelis@awi.de (A. Müller-Michaelis).
}

investigating accumulation rates of sediment drifts in the northern North Atlantic, Wold (1994), however, found that drift building at the Eirik Drift may have started 7-8 Ma ago. The study regarding the North Atlantic deep circulation by Wright and Miller (1996) is based on the findings of Wold (1994), but dates the onset of drift accumulation at Eirik Drift at 5-6 Ma. This date of onset of drift building at the Eirik Drift is used in further investigations by several authors (e.g. Wright, 1998; Cramer et al., 2009; Miller et al., 2009). On the other hand, recent works of Hunter et al. (2007a) and Hunter et al. (2007b) based their investigations at the Eirik Drift on the interpretation from Arthur et al. (1989) with the onset of deep-current controlled sedimentation at $4.5 \mathrm{Ma}$. In this study, we aim to reappraise the question of the timing of the onset of drift accumulation at Eirik Drift on the basis of an analysis of a tight grid of newly collected seismic reflection data. We incorporate these seismic data with geological information and age-models of Ocean Drilling Program (ODP)/Integrated Ocean Drilling Program (IODP) drill sites, including ODP Leg 105 Site 646 and IODP Expedition 303 Sites U1305, U1306 and U1307 in a bid to better define the inception of drift growth offshore southern Greenland (Figs. 1 and 2).

\section{Settings}

\subsection{Geological settings and drift morphology}

The Labrador Sea basin is about $900 \mathrm{~km}$ wide and opens to the SE into the North Atlantic (Fig. 1; Chalmers and Pulvertaft, 2001). This basin formed as a consequence of continental rifting between 

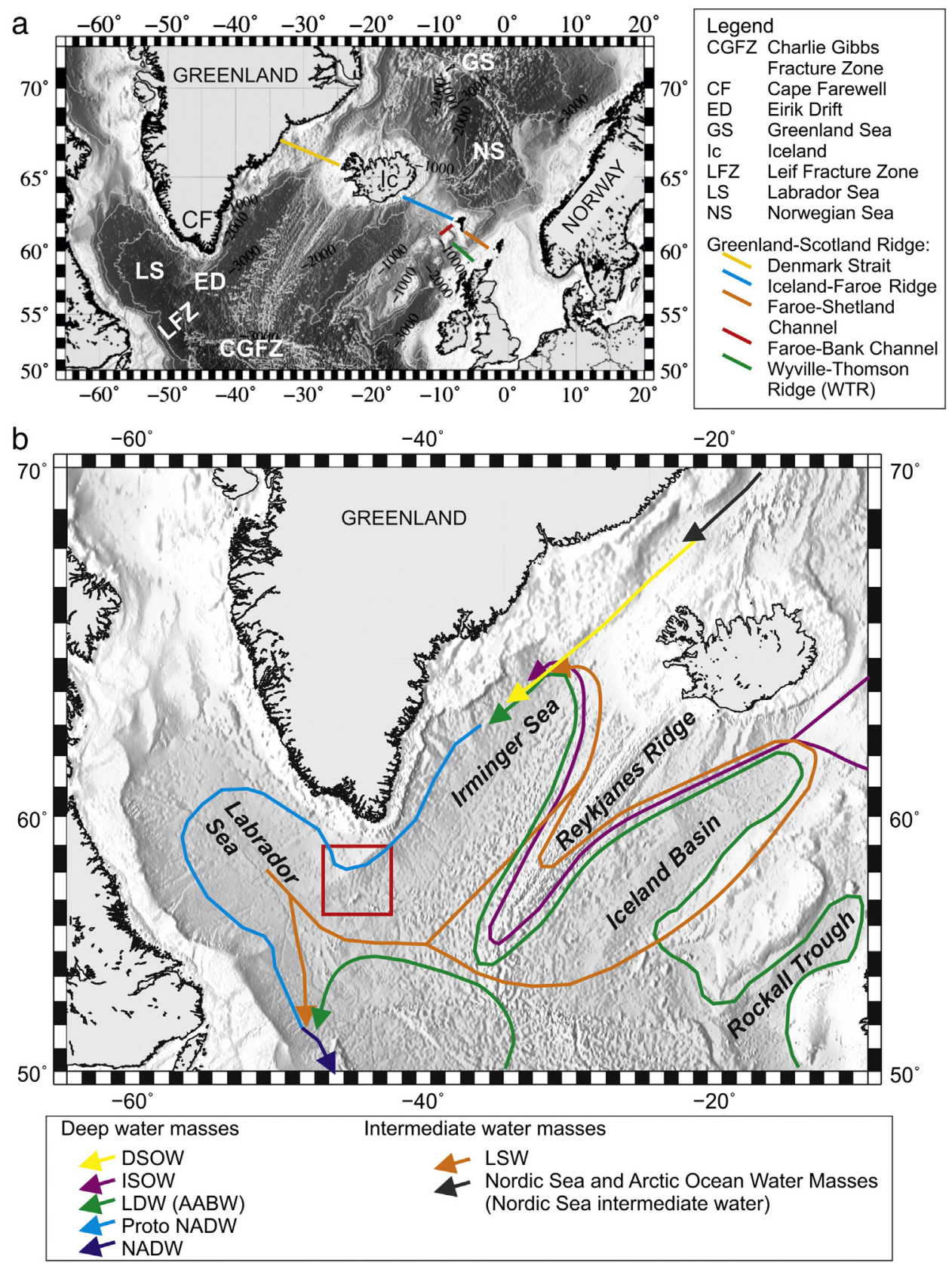

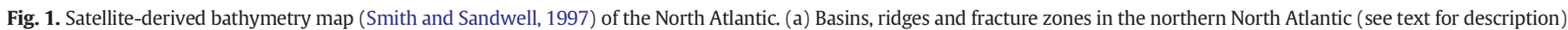

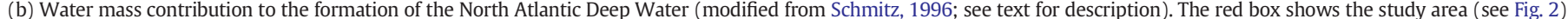

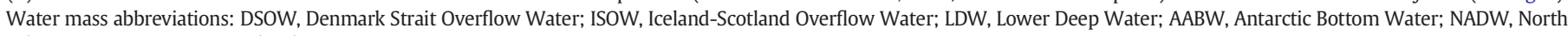
Atlantic Deep Water; LSW, Labrador Sea Water.

Greenland and Labrador, which commenced during the Late Cretaceous (anomaly 27, 63 Ma) (Chalmers and Pulvertaft, 2001), but had ceased by 35 Ma ago (Srivastava and Roest, 1999). The Eirik Drift is located in the eastern part of the Labrador Sea, south of the southern tip of Greenland (Fig. 1). Two narrow parallel WSW-trending basement ridges, which formed during the rifting process between about 61 and $40 \mathrm{Ma}$ (Mueller et al., 2008), underlie the Eirik Drift (Fig. 2; Le Pichon et al., 1971; Srivastava and Arthur, 1989). These basement elevations are believed to have controlled the onset of drift building in this region (Srivastava and Arthur, 1989; Hunter et al., 2007b). At present, the main Eirik Drift crest extends from a water depth of $1500 \mathrm{~m}$ in the NE to $\sim 3600 \mathrm{~m}$, and extends a total length of $360 \mathrm{~km}$ in the SW over these basement ridges (Fig. 2; Hunter et al., 2007a). The Eirik Ridge is classified as a detached giant elongated drift formed under the influence of deep contour currents (e.g. Stow et al., 1998; Faugères et al., 1999). Hunter et al. (2007a) reported three NW-trending subsidiary ridges, which extend to the NW from the main drift crest (Fig. 2).

The Greenland-Scotland-Ridge (GSR; Fig. 1a) is the gateway for northern-sourced deep-water into the northern North Atlantic. Therefore, its formation and subsidence history is important for the evolution of the Eirik Drift but has yet to be fully understood. The western part of the GSR between Greenland and Iceland is called the Denmark Strait (Fig. 1a). Here, first significant overflow was observed at $\sim 7 \mathrm{Ma}$ (Bohrmann et al., 1990) and the present sill depth lies at $\sim 620 \mathrm{~m}$ (Hansen and Østerhus, 2000). The eastern part of the GSR is a complex ridge-channel-system (Fig. 1). The Iceland-Faroe-Ridge with a present maximum sill depth of $\sim 480 \mathrm{~m}$ (Hansen and Østerhus, 2000) experienced first significant overflows at 13-11 Ma (Bohrmann et al., 


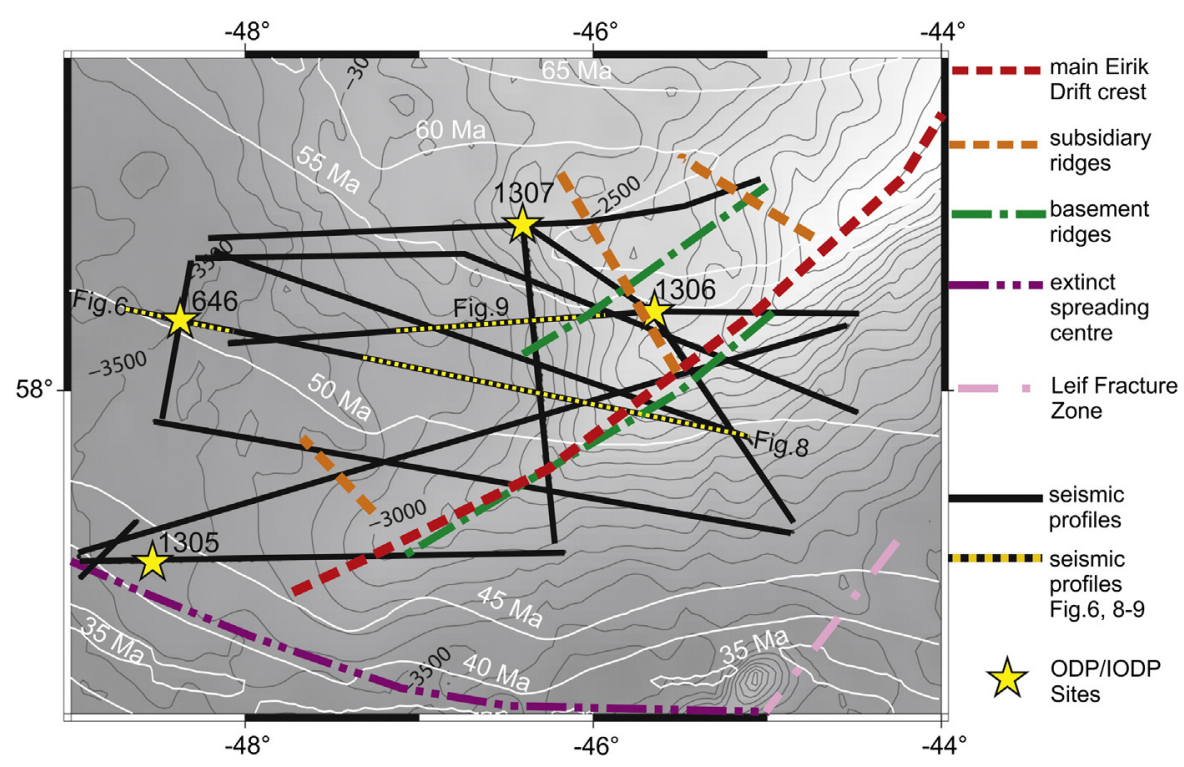

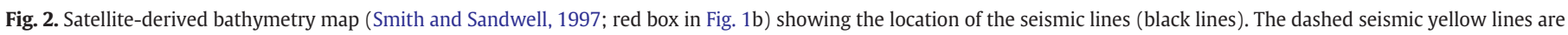

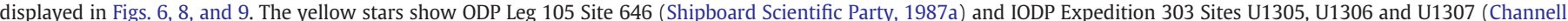

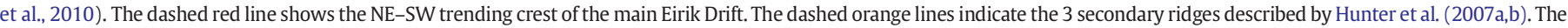

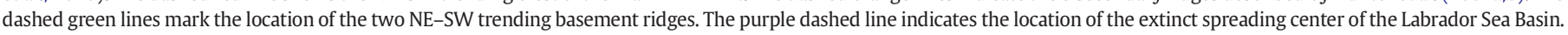
The pink dashed line shows the Leif Fracture Zone. The white contour lines mark the oceanic basement age (Mueller et al., 2008).

1990). The deepest part of the GSR is the Faroe Conduit ( $840 \mathrm{~m})$, a pathway through the Faroe-Shetland Channel into the Iceland Basin via the Faroe Bank Channel (Fig. 1; Hansen and Østerhus, 2000). The Faroe Conduit developed in early Miocene and is suggested as the first true deep-water connection between the Nordic Seas and the Atlantic (Stoker et al., 2005). Sufficient subsidence of the GSR with first overflows at the distal eastern part of the GSR into the Rockall Trough (Fig. 1) is suggested for the early Oligocene (Davies et al., 2001). The sill between the Faroe-Shetland Chanel and the Rockall Trough is called WyvilleThomson Ridge and has a present sill-depth of $\sim 600 \mathrm{~m}$ (Fig. 1; Hansen and Østerhus, 2000). The main deep-water connection of the Arctic Ocean to the Nordic Seas, the Fram Strait, occurred concomitant with the development of the Faroe Conduit (Ehlers and Jokat, 2013).

\subsection{Present-day oceanographic setting}

At present, the Western Boundary Undercurrent (WBUC) is the active deep current in the vicinity of the Eirik Drift. In this region, it is located between the $1900 \mathrm{~m}$ and $3000 \mathrm{~m}$ isobaths and composed of four main water masses: Denmark Strait Overflow Water (DSOW), IcelandScotland Overflow Water (ISOW), Labrador Sea Water (LSW) and modified Antarctic Bottom Water (AABW) (Dickson and Brown, 1994; Schmitz, 1996). Convective mixing in the Greenland and Norwegian Seas together with Arctic Ocean outflow forms Nordic Sea intermediate and deep water (Fig. 1; Hansen and Østerhus, 2000). These overspill the shallow Greenland-Scotland Ridge (GSR) via the Denmark Strait ( $620 \mathrm{~m}$; DSOW) and the Iceland-Scotland Ridge (ISOW), mainly through the Faroe-Conduit ( $840 \mathrm{~m})$ (Fig. 1; Hansen and Østerhus, 2000). While descending into the northern North Atlantic, these overflows entrain LSW and Lower Deep Water (LDW) (Fig. 1). LSW is formed by convective overturning in the Labrador Sea and is found at depths between 700 and $1500 \mathrm{~m}$ off the east coast of Greenland (Fig. 1; Dickson and Brown, 1994; Schmitz, 1996). LDW is modified AABW. It flows northward from its formation point in the Antarctic as bottom current (below $3000 \mathrm{~m}$ ) and entrains ambient waters on its way (Dickson and Brown, 1994; Schmitz, 1996). The overflows, including the entrained water masses, together form the WBUC off the east coast of Greenland (Fig. 1; Dickson and Brown, 1994; Schmitz, 1996). ISOW forms the upper layer of the WBUC with a core depth around $2000 \mathrm{~m}$ and DSOW forms the lower layer with a core depth around $3000 \mathrm{~m}$ off Cape Farewell (Dickson and Brown, 1994; Schmitz, 1996). The WBUC entrains more surrounding water masses on its way through the Labrador Basin and is modified to North Atlantic Deep Water (NADW) (Fig. 1; Hansen and Østerhus, 2000). NADW is the main contributor to the lower limb of the present day North Atlantic THC (Dickson and Brown, 1994; Schmitz, 1996). As the composition and pathways of the ancient northern-sourced deep-water are not well known, the precursor of the present NADW is called Northern Component Water (NCW).

\section{Data and methods}

\subsection{Seismic reflection data}

In 2009, the Alfred Wegener Institute for Polar and Marine Research gathered $\sim 2000 \mathrm{~km}$ of high-resolution seismic reflection data in the area of the Eirik Drift south of Greenland with the German research vessel Maria S. Merian (Fig. 2). Four GI-guns $\bigodot$, with a volume of about 1.41 each, were used as a seismic source. Each of the GI-guns@ consisted of a generator chamber ( 0.721 volume) that produced the seismic signal, and an injector chamber (1.68 l volume), which was triggered with a $33 \mathrm{~ms}$ delay to suppress the bubble. The GI-guns@ were fired every $10 \mathrm{~s}$ (corresponding to a shot-spacing of approximately $25 \mathrm{~m}$ ), producing signals with frequencies of up to $300 \mathrm{~Hz}$. Data with a sample interval of $1 \mathrm{~ms}$ were received using a high-resolution seismic data acquisition system (SERCEL SEALC), consisting of both onboard and in-sea equipment. The total active streamer length was $3000 \mathrm{~m}$, consisting of 240 channels, and additionally a lead-in cable length of $191 \mathrm{~m}$. Navigation data were specified by GPS (Global Positioning System).

Processing of the seismic reflection data comprised geometry definition using the ship's navigation data, and Common Depth Point (CDP) sorting with a CDP spacing of $25 \mathrm{~m}$. A precise velocity analysis (every $50 \mathrm{CDP}$ ) was carried out and used for normal moveout correction. After stacking, a time-migration was carried out (Omega-X migration) (Yilmaz, 2001). Band filtering with tapering (Hanning window) 
with the boundaries 20-25 Hz and 200-250 Hz, but no AGC (Automatic Gain Control) was applied to the data for display.

\section{2. $O D P / I O D P$ data}

The seismic survey was designed to image the seismic reflection geometry of the Eirik Drift and intersect four ODP and IODP scientific boreholes in the area (Fig. 2). The following description of ODP Leg 105 Site 646 (ODP 646) is derived from Srivastava et al. (1989) and Cremer (1989); results from IODP Expedition 303 Sites U1305-U1307 are taken from Channell et al. (2010), Channell et al. (2006), Expedition 303 Scientists (2006) and Shipboard Scientific Party (2005).

\subsubsection{ODP Leg 105 Site 646 (ODP 646)}

ODP 646 lies in the west of the study area at a water depth of $3450 \mathrm{~m}$ (Fig. 2). The borehole recovered $766.7 \mathrm{~m}$ of dominantly fine-grained, terrigenous sediments, which comprise two major lithological units ranging back to the Late Miocene (Fig. 3). For the entire drilled sequence, sedimentation rates average about $9.1 \mathrm{~cm} / \mathrm{ka}$.

\subsubsection{IODP Expedition 303 Site U1305 (IODP 1305)}

IODP 1305 is located $82.2 \mathrm{~km}$ south of ODP 646, in the SW corner of our study area at a water depth of $3459 \mathrm{~m}$ (Fig. 2). A single Quaternary lithologic unit of $295 \mathrm{~m}$ was obtained (Fig. 3), which documents the last $1.77 \mathrm{Ma}$ and is dominated by varying mixtures of terrigenous components and biogenic material. The mean sedimentation rate for the drilled sequence is assumed to be $17.3 \mathrm{~cm} / \mathrm{ka}$ using biostratigraphic and magnetostratigraphic data.

\subsubsection{IODP Expedition 303 Site U1306 (IODP 1306)}

IODP 1306 is located in the NE of the study area (Fig. 2) at a water depth of $2274 \mathrm{~m}$. Drilling at IODP 1306 proved sediment as old as $1.95 \mathrm{Ma}$ at a depth of $309.3 \mathrm{~m}$. The single lithological unit consists of Quaternary terrigenous and biogenic sediments (Fig. 3), which are gradationally interbedded at scales of a few meters or less. The mean sedimentation rate for the drilled sequence was estimated to be $18 \mathrm{~cm} / \mathrm{ka}$ by means of biostratigraphic and magnetostratigraphic data.

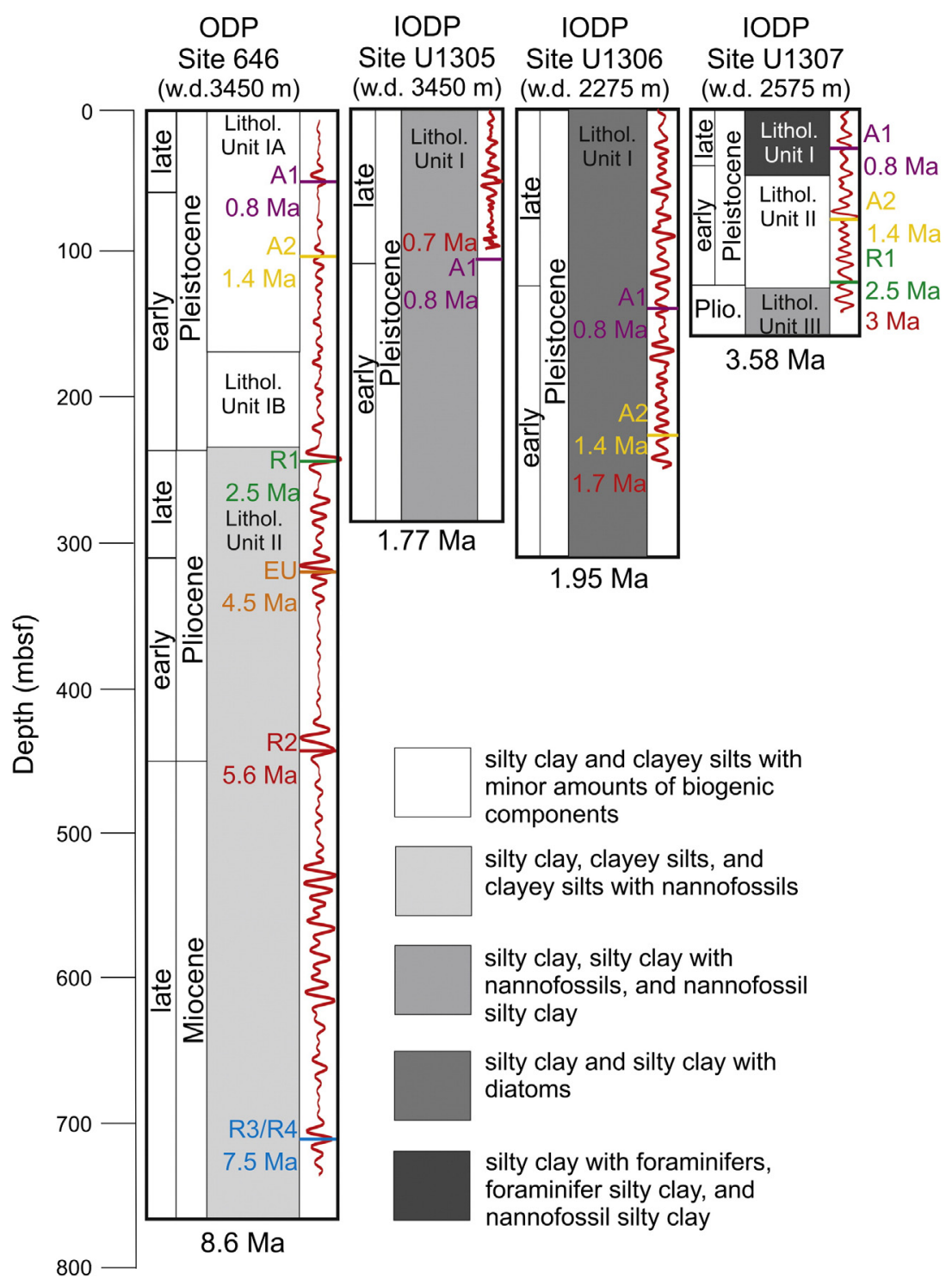

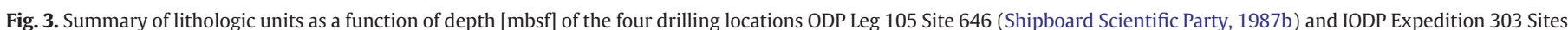

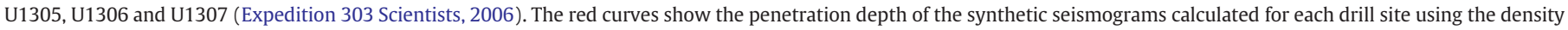

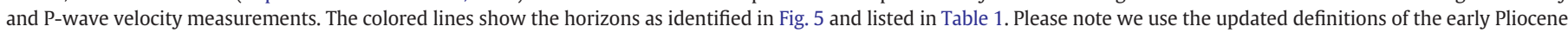
(5.332-3.6 Ma), late Pliocene (3.6-2.588 Ma), and early Pleistocene (2.588-0.781 Ma) (Gibbard et al., 2010). W.d. Water depth. 


\subsubsection{IODP Expedition 303 Site U1307 (IODP 1307)}

IODP 1307 is located $53 \mathrm{~km}$ northwest of IODP 1306 (Fig. 2) at a water depth of $2575 \mathrm{~m}$. This borehole cored $162.6 \mathrm{~m}$ of Upper PlioceneHolocene sediments that comprise 3 lithologic units extending back to 3.58 Ma with variations in input of terrigenous and biogenic components (Fig. 3). Apart from one possible hiatus (1.2-1.4 Ma; 56-61 mbsf) the sedimentary record at IODP 1307 appears continuous with a mean sedimentation rate of $4.8 \mathrm{~cm} / \mathrm{ka}$.

\subsubsection{Conversion of ODP/IODP logs to synthetic seismic data}

Density and P-wave velocity data from the drill sites are needed to calculate synthetic seismograms, which enable a correlation of the seismic data with geological information (database: http://www-odp. tamu.edu/ or http://brg.ldeo.columbia.edu/data/odp/leg105/646B/).

For ODP 646 Gamma ray attenuation (GRA) measurements with the whole core multi-sensing track tool (MST) provide GRA Bulk density data with a resolution of $0.006 \mathrm{~m}$ extending from 0.006 to 758.948 mbsf (Fig. 4a). Sonic velocity measurements of the split core are provided with only a very low resolution (in irregular intervals in the order of tens of meters). Downhole measurements conducted with a long spacing Sonic Tool provide seismic P-wave velocity data with a resolution of $0.15 \mathrm{~m}$ but only in the interval 208.788 to $744.931 \mathrm{mbsf}$. Therefore, a complementary combination of the downhole loggings and the laboratory measurements of the split core is used and spurious P-wave velocity data $(<1400 \mathrm{~m} / \mathrm{s})$ are removed. The resulting P-wave velocity log is shown in Fig. $4 \mathrm{a}$. The black line marks the boundary between low-resolution split core measurements in the upper $208 \mathrm{~m}$ and the high-resolution downhole log.

The physical properties of IODP 1305-1307 were measured on whole-round core sections run through a MST and led to bulk density and seismic velocity data with a resolution of $0.05 \mathrm{~m}$. Unfortunately, P-wave velocity measurements are not available for the same depth range as the density logs; hence, the synthetic seismograms do not cover the total depth drilled (Fig. 3). Data processing comprised elimination of loops and spurious data, extrapolation to the starting depth of $0 \mathrm{mbsf}$ and interpolation (resampling) for missing data and adjusting the sample intervals. A depth-time-conversion using the P-wave velocity data (sonic log) was carried out and the data were resampled to $1 \mathrm{~ms}$ to fit to the sample rate of our seismic data. Acoustic impedance and the reflection coefficients were computed. Wildeboer Schut and Uenzelmann-Neben (2006) showed that the convolution of the reflection coefficients with an artificial Ricker wavelet (Ricker, 1953 ) yields better results than synthetics obtained by application of a wavelet estimated from the seismic data. Therefore, Ricker wavelets in the frequency range between 20 and $250 \mathrm{~Hz}$ were applied to the reflection coefficients. The applied Ricker wavelets of lower frequencies bear a loss of resolution while high-frequency wavelets introduce reflectors, which are not observed in the seismic data. The convolution of the reflectivity series with a $70 \mathrm{~Hz}$ Ricker wavelet correlated best with the seismic data and therefore was used to generate the synthetic seismograms. The processed density and velocity data, the calculated impedance, reflection coefficients and the resulting synthetic traces in time domain (TWT) for all sites are shown on the right in Fig. 4 (4b: ODP 646; 4d: IODP 1305; 4f: IODP 1306; 4h: IODP 1307). No filters were applied to the synthetic seismograms.

\section{Results}

\subsection{Correlation of geological and seismic data and seismostratigraphic} model

The synthetic seismic data are compared and correlated with the recorded seismic data and thus, age control of the seismic data is possible (Fig. 5). Following the stratigraphy defined by Arthur et al. (1989), we identified horizon R1 (4.9 s TWT; Fig. 5a and b), an erosional unconformity (EU) which marks the boundary between seismic units SUII and
SUIII (5.0 s TWT; Fig. 5a and b), horizon R2 (5.1 s TWT; Fig. 5a and b), reflector doublet R3/R4 (5.4 s and $5.45 \mathrm{~s}$ TWT; Fig. 5a and b) and below penetration depth horizon R5 (5.7 s TWT; Fig. 5b) and the basement reflector (5.9 s TWT; Fig. 5b) at the location of ODP 646 (Table 1). Three additional horizons were defined at ODP 646 (Fig. 5a and b; Table 1). Two horizons, A1 (4.65 s TWT; Fig. 5a and b) and A2 (4.7 s TWT; Fig. 5a and b), were defined within unit SUI, and horizon A3 (5.8 s TWT, Fig. 5b) within unit SUIV (Table 1). We extrapolated the identified and defined horizons at ODP 646 to our whole seismic grid. The synthetic seismograms of the shallow sites IODP 1305-1307 were also correlated with the seismic data (Fig. 5c-e). Using the sedimentation rates of each borehole proved to be consistent with our extrapolation of the upper horizons (Fig. $5 \mathrm{c}-\mathrm{e}$ ).

The definition of Seismic Units and the description of their seismic characteristics outlined in the following and summarized in Table 1 are conducted in the vicinity of ODP 646 in the western part of the study area (Fig. 6).

\subsubsection{Seismic Unit I}

Unit SUI corresponds to Lithologic Unit I (Fig. 3) and extends from the seafloor to medium- to high-amplitude horizon R1 (Fig. 5a and b; Fig. 6). Unit SUI is 270 to $400 \mathrm{~ms}$ thick and characterized by high amplitude reflections that are parallel to subparallel to the seafloor (Fig. 6). The lithological texture of unit SUI is marked by scattered coarse particles up to cobble size, which disappear at its base (Cremer, 1989). This base, horizon R1, is dated to $2.5 \mathrm{Ma}$, and related to the onset of major ice rafting around the Pliocene/Pleistocene boundary (Arthur et al., 1989). The division into two lithologic subunits, IA and IB (Fig. 3), is based on a lower carbonate content ( $<10 \mathrm{wt}$.\%) and a higher content of granule-sized particles in the lower lithologic subunit IB (Cremer, 1989). This subdivision is not used for our seismostratigraphic model.

We defined medium- to high-amplitude horizons A1 and A2 within unit SUI (Fig. 5a and b; Fig. 6). The sedimentation rate at ODP 646 was used to date these horizons. Horizon A1 lies at the boundary from Early to Mid-Pleistocene (0.8 Ma; Fig. 3). Subunit SUI-a, embedded between the seafloor and horizon A1, is 100 ms TWT thick and comprises continuous high-amplitude parallel reflections (Fig. 6). Subunit SUI-b extends between the high-amplitude horizons A1 and A2, which is dated at $1.4 \mathrm{Ma}$. Subunit SUI-b is also about $100 \mathrm{~ms}$ TWT thick, but characterized by medium amplitude, narrow-spaced $(<0.01 \mathrm{~s}$ TWT), continuous to discontinuous, parallel reflections (Fig. 5a and b; Fig. 6). Subunit SUI-c is bordered by horizon A2 at the top and medium- to high-amplitude horizon R1 at the base. It comprises the lower part of Lithologic subunit IA and Lithologic subunit IB (Fig. 3). Subunit SUI-c thins from $200 \mathrm{~ms}$ TWT in the west to $100 \mathrm{~ms}$ TWT in the east (Fig. 6). The broad-spaced (0.04 s TWT), continuous to discontinuous, parallel to subparallel internal reflections increase in amplitude from its base to the top and converge towards the east (Fig. 5a and b; Fig. 6).

\subsubsection{Seismic Unit II}

Unit SUII is bordered by horizon R1 at the top and the erosional unconformity EU at the bottom, which appears as a high-amplitude horizon. Here, changes in grain size, sorting (Cremer, 1989) and foraminiferal assemblages (Kaminski et al., 1989) were observed. Arthur et al. (1989) defined the base of unit SUII, which is dated at 4.5 Ma, as the basal unconformity of the drift. Unit SUII is $100-140$ ms thick, rises from the west to the east and consists of many narrow-spaced $(<0.01 \mathrm{~s}$ TWT), continuous high amplitude reflections (Fig. 5a and b; Fig. 6).

\subsubsection{Seismic Unit III}

Unit SUIII extends between the erosional unconformity and the reflection doublet R3/R4 and thickens from $350 \mathrm{~ms}$ TWT in the west to $550 \mathrm{~ms}$ TWT in the east (Fig. 6). The basal reflection doublet R3/R4 consists of two medium- to high-amplitude, continuous to discontinuous 

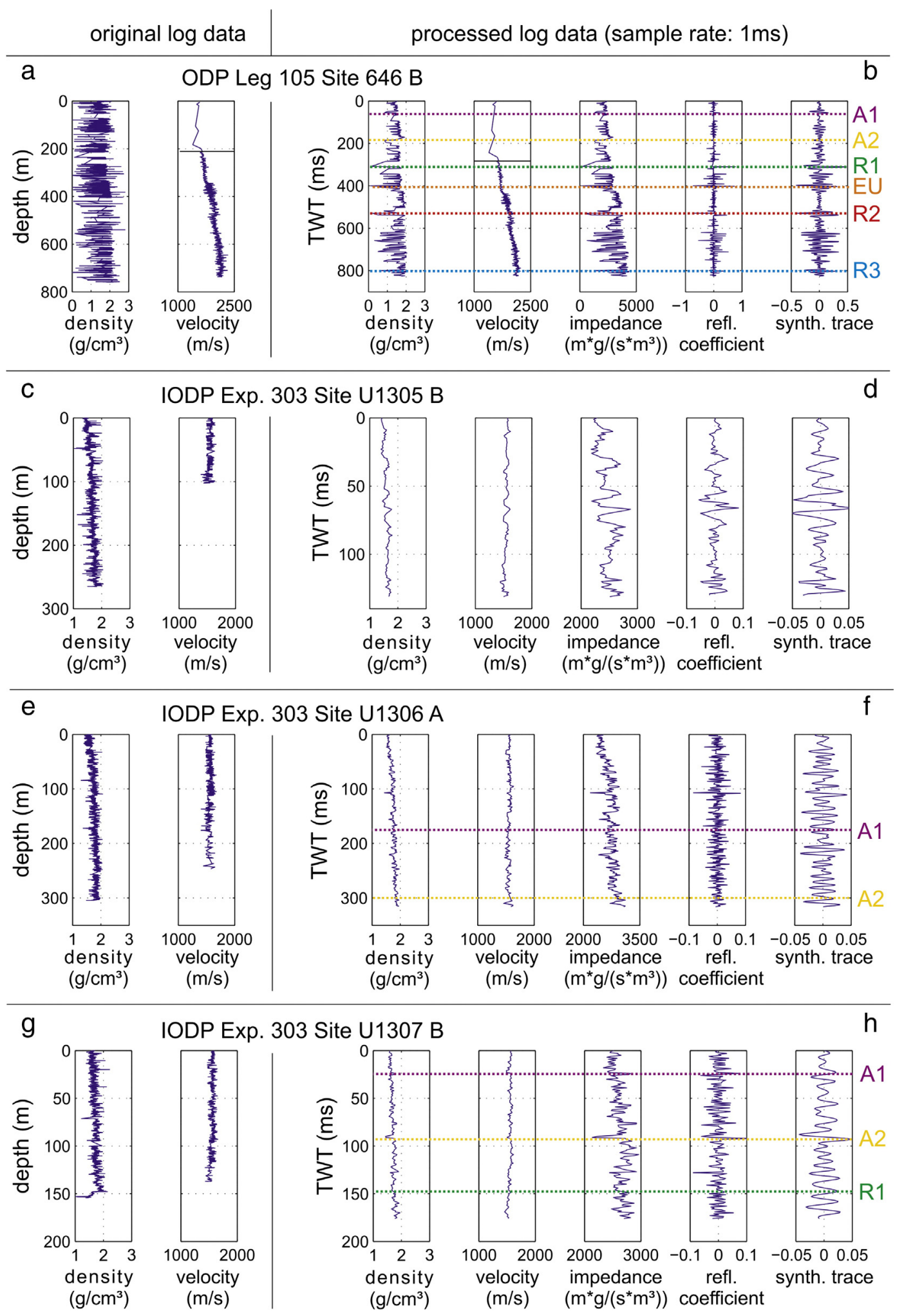

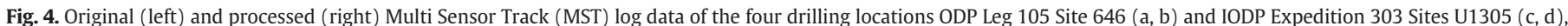

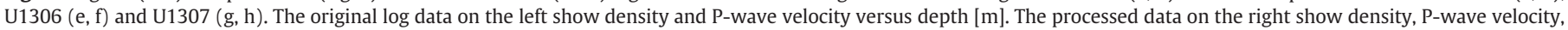

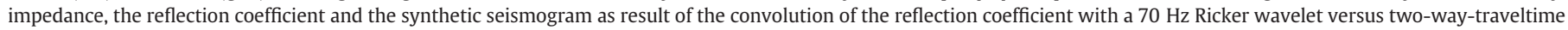
[TWT]. The colored lines show the horizons as identified in Fig. 5 and listed in Table 1.

reflections with a mean spacing of $\sim 50 \mathrm{~ms}$ TWT (Fig. 5a and b; Fig. 6; Figs. 8-9). Unit SUIII is subdivided by the medium amplitude horizon R2 (Fig. 5a and b; Fig. 6). Horizon R2 as well as reflection doublet R3/R4 mark changes in the carbonate content (Kaminski et al., 1989).
Subunit SUIII-a is dated at 4.5-5.6 Ma (Arthur et al., 1989) and thickens from $100 \mathrm{~ms}$ TWT in the west to $300 \mathrm{~ms}$ TWT in the east. Amplitudes of, and spacing between, the internal reflections increase towards the top of subunit SUIII-a (Fig. 5a and b; Fig. 6). In the east, 


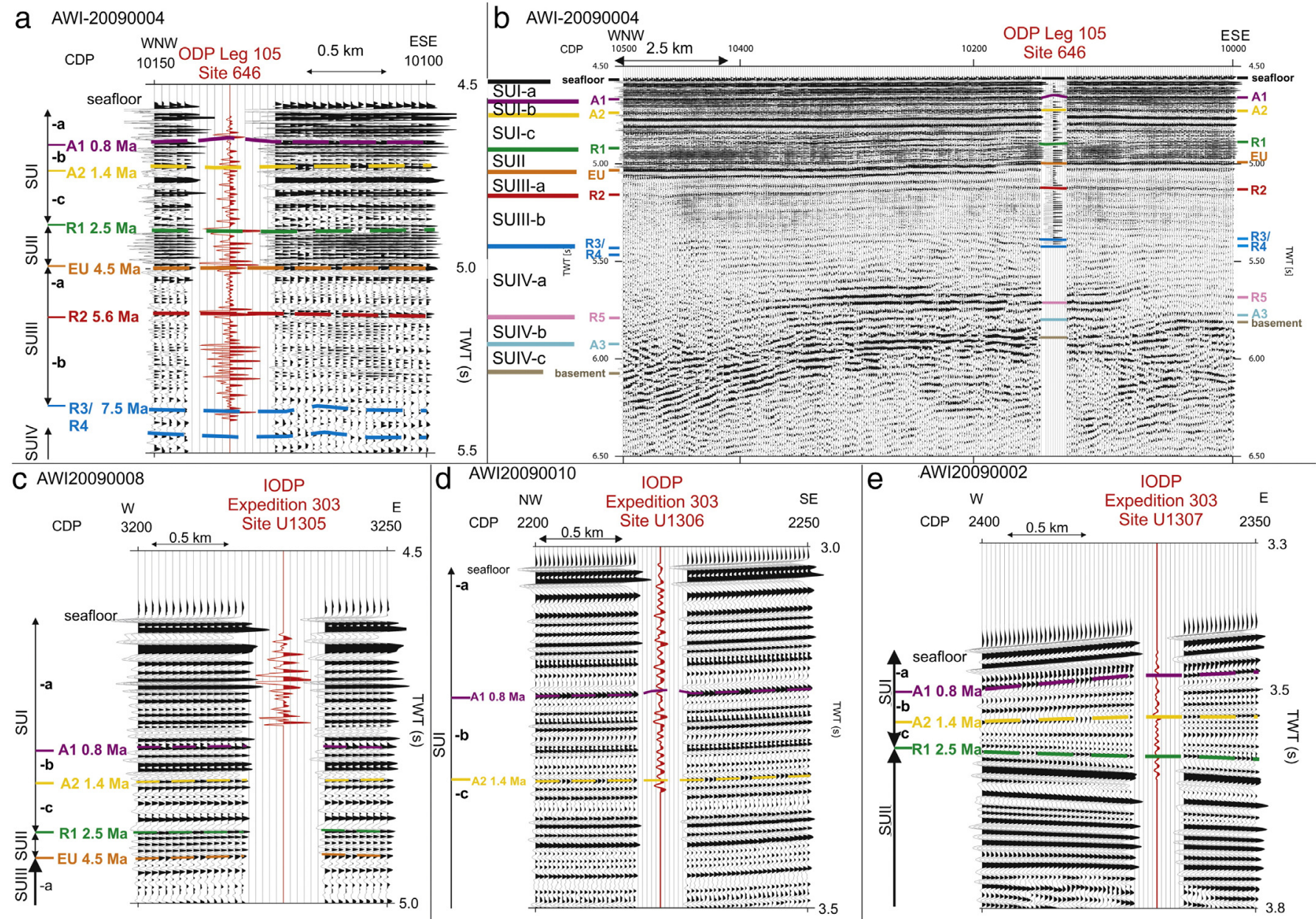

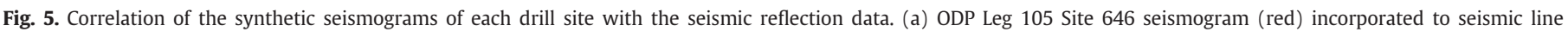

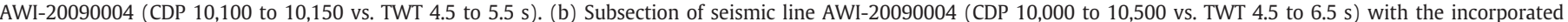

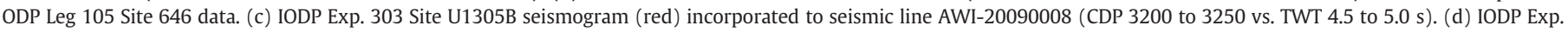

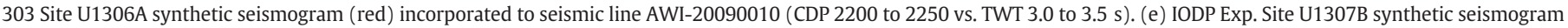
(red) incorporated to seismic line AWI-20090002 (CDP 2350 to 2400 vs. TWT 3.3 to 3.8 s). Seismic Units (SUI-IV) and horizons (A1-A3, R1-R5, EU) are as listed in Table 1.

reflector truncations are observed at the erosional unconformity (Fig. 6). Subunit SUIII-b is between 150 and 300 ms TWT thick and consists of narrowly spaced $(<0.01 \mathrm{~s}$ TWT) parallel to subparallel mainly low amplitude reflections (Fig. 5a and b; Fig. 6). Subunit SUIII-b is dated as 5.6-7.5 Ma (Arthur et al., 1989).

\subsubsection{Seismic Unit IV}

Unit SUIV is bordered at the top by the medium- to high-amplitude reflector doublet R3/R4, which is underlain by many diffractions, and the irregular acoustic basement horizon that forms the top of the oceanic crust between 5.8 and $6.2 \mathrm{~s}$ TWT (Fig. 6). The thickness of unit SUIV varies between 350 and 700 ms TWT due to the roughness of the basement. The top reflector doublet R3/R4 is dated at $7.5 \mathrm{Ma}$ (Arthur et al., 1989). The basement underlying the region of ODP 646 is dated 50-51 Ma (Fig. 2) (Mueller et al., 2008).

Unit SUIV is subdivided by the internal horizons R5 and A3, which lie beneath the drilling penetration depth of site ODP 646 (Figs. 5b and 6). Using the sedimentation rate of the upper part of unit SUIV, the ages of horizons R5 and A3 are estimated as middle Miocene (10-12 Ma) and early Miocene (17-19 Ma), respectively. However, considering the age of the underlying basement, the sedimentation rate within unit SUIV must be much lower and/or there must be hiatuses within this unit. The age estimation of these horizons will be discussed in detail later. Horizon R5 lies within a band of 3-4 high-amplitude reflections at depth between 5.6 and 5.7 s TWT. Besides this band and the top reflector doublet R3/R4, subunit SUIV-a consists of low amplitude, parallel to subparallel reflections and is 200 to $300 \mathrm{~ms}$ TWT thick (Fig. 6). Subunit SUIV-b lies between the high-amplitude horizons R5 and A3. Subunit SUIV-b thins from $250 \mathrm{~ms}$ TWT in the west to $50 \mathrm{~ms}$ TWT in the east, where the low- to medium amplitude internal reflections converge (Fig. 6). Horizon A3 lies mainly closely above the acoustic basement reflection (50-100 ms TWT), but terminates against basement highs and lies almost horizontally above basement troughs (Fig. 6). Therefore, subunit SUIV-c varies in thickness from 0 to $250 \mathrm{~ms}$ TWT. Subunit SUIV-c appears almost acoustically transparent.

\subsection{Detailed description of the Miocene unit SUIV}

For a detailed investigation of the different sedimentary environments at the Eirik Drift, we tracked the horizons from the acoustic basement to the seafloor and computed the different unit and subunit thicknesses. In this study, we want to concentrate on unit SUIV and therefore on the early stages of drift development during the Miocene. The drift development after 7.5 Ma (horizon R3/R4) will be the focus of further studies. In Fig. 7, the outlines of the interface horizons (left) and the (sub)unit thicknesses (right) of unit SUIV are depicted. Interface depth values shallower than its root mean square (rms) value are defined to represent topographic highs of the horizon in question 
Table 1

Refined seismic stratigraphy and reflector nomenclature at ODP Leg 105 Site 646.

\begin{tabular}{|c|c|c|c|c|c|c|c|}
\hline \multicolumn{3}{|c|}{$\begin{array}{l}\text { Geological } \\
\text { record from } \\
\text { ODP } 646\end{array}$} & \multirow[t]{2}{*}{$\begin{array}{l}\text { Age } \\
\text { [Ma] }\end{array}$} & \multirow{2}{*}{\begin{tabular}{|l}
$\begin{array}{l}\text { Reflectorl } \\
\text { unit } \\
\text { name }\end{array}$ \\
SUI-a
\end{tabular}} & \multirow[t]{2}{*}{$\begin{array}{l}\text { Depth at } \\
\text { ODP } 646 \\
\text { [ms TWT] }\end{array}$} & \multirow{2}{*}{$\begin{array}{l}\text { Thickness } \\
\text { (min/max) } \\
\text { [ms TWT] }\end{array}$} & \multirow{2}{*}{$\begin{array}{l}\text { Seismic characteristic } \\
\begin{array}{l}\text { continuous high amplitude reflctions, parallel } \\
\text { to subparallel to seafloor }\end{array}\end{array}$} \\
\hline \multirow{5}{*}{ 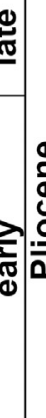 } & & \multirow{4}{*}{$\begin{array}{l}\text { Lithol. } \\
\text { Unit IA }\end{array}$} & & & & & \\
\hline & & & 0.8 & A1 & 456 & & High-amplitude reflector \\
\hline & 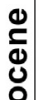 & & & SUI-b & & $100 / 100$ & $\begin{array}{l}\text { continuous to discontinuous, narrowly- } \\
\text { spaced, parallel medium amplitude } \\
\text { reflections }\end{array}$ \\
\hline & 至 & & 1.4 & A2 & 470 & & High-amplitude reflector \\
\hline & & $\begin{array}{l}\text { Lithol. } \\
\text { Unit IB }\end{array}$ & & SUI-c & & $100 / 200$ & $\begin{array}{l}\text { wide-spaced, continuous to discontinuous, } \\
\text { parallel to subparallel reflections, upward } \\
\text { increase in amplitudes }\end{array}$ \\
\hline \multirow{4}{*}{ 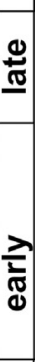 } & \multirow{4}{*}{ 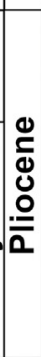 } & \multirow{7}{*}{$\begin{array}{l}\text { Lithol. } \\
\text { Unit II }\end{array}$} & 2.5 & R1 & 490 & & Medium- to high amplitude reflector \\
\hline & & & & SUII & & $100 / 140$ & $\begin{array}{l}\text { narrowly-spaced, continuous high-amplitude } \\
\text { reflections } \\
\text { unit rises from } \mathrm{W} \text { to } \mathrm{E}\end{array}$ \\
\hline & & & 4.5 & EU & 500 & & $\begin{array}{l}\text { Erosional unconformity } \\
\text { high-amplitude reflector } \\
\text { reflector truncation }\end{array}$ \\
\hline & & & & SUIII-a & & $100 / 300$ & $\begin{array}{l}\text { upward increase in amplitudes and reflector } \\
\text { spacing } \\
\text { unit thickens from W to } E\end{array}$ \\
\hline \multirow{3}{*}{ 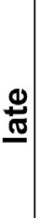 } & \multirow{3}{*}{\begin{tabular}{l}
$\mathbf{y}$ \\
$\mathbf{c}$ \\
$\mathbf{u}$ \\
$\mathbf{0}$ \\
\hdashline
\end{tabular}} & & 5.6 & R2 & 510 & & Medium-amplitude reflector \\
\hline & & & & SUIII-b & & $150 / 300$ & $\begin{array}{l}\text { narrowly-spaced, parallel to subparallel, low- } \\
\text { amplitude reflections }\end{array}$ \\
\hline & & & $\begin{array}{l}7.5 \prime \\
8.1\end{array}$ & $\begin{array}{l}\text { R3/ } \\
\text { R4 }\end{array}$ & $\begin{array}{l}540 / \\
545\end{array}$ & & $\begin{array}{l}\text { medium- to high-amplitude reflector } \\
\text { doublet }\end{array}$ \\
\hline & & & & SUIV-a & & $200 / 300$ & $\begin{array}{l}\text { parallel to subparallel, low-amplitude } \\
\text { reflections }\end{array}$ \\
\hline & & & $10-12$ & R5 & 570 & & band of 3-4 high-amplitude reflections \\
\hline & & & & SUIV-b & & $50 / 250$ & $\begin{array}{l}\text { converging, low- to medium-amplitude } \\
\text { reflections } \\
\text { unit thins from } W \text { to } E\end{array}$ \\
\hline & & & $17-19$ & A3 & 580 & & High-amplitude reflector \\
\hline & & & & SUIV-c & & $0 / 250$ & almost acoustically transparent \\
\hline & & & $40-60$ & basement & 590 & & irregular basement topography \\
\hline
\end{tabular}

(Fig. 7 left). A depocenter is defined as the part of the thickness maps which is thicker than the rms value (Fig. 7 right).

The seismic basement represents the top of the oceanic crust, which on all seismic sections appears as a high-amplitude reflection with an irregular, hummocky topography, characterized by several local highs (Figs. 6, 7a, and 8-9). The rms depth of the basement lies at $\sim 5500$ ms TWT (Fig. 7a). Its outline encircles smaller basement elevations in the NW, SW, and the NE corner of the study area with a branch extending towards the basement highs in the SW (Fig. 7a). These basement highs are aligned along the axes of the WSWtrending basement ridges (Fig. 7a) (Le Pichon et al., 1971; Srivastava and Arthur, 1989). The basement slopes from the NE at $~ 3800 \mathrm{~ms}$ TWT to the WSW at $\sim 6500 \mathrm{~ms}$ TWT (Fig. 7a).

Unit SUIV lies above the seismic basement (Fig. 7b), with its top being formed by reflector doublet R3/R4 of late Miocene age (Arthur et al., 1989). Horizon doublet R3/R4 slopes from $3260 \mathrm{~ms}$ TWT in the ENE to $5670 \mathrm{~ms}$ TWT in the WSW (Fig. 7c). Due to the irregular basement below (Fig. 7a) the thickness of unit SUIV is highly variable ranging from 0 to 1570 ms TWT (Fig. 7b). The part of unit SUIV with a thickness of $>860 \mathrm{~ms}$ TWT is defined as its depocenter. This depocenter covers the SE study area with two branches extending to the WNW and $\mathrm{N}$ (Fig. 7b). The depocenter appears attached to the SW flank of topographic high of the basement partly crossing the lower part of the topographic high in the south (Fig. 7a and b). Unit SUIV is subdivided into 3 subunits SUIV-a, -b and -c by the internal high-amplitude reflectors A3 and R5 (Table 1; Figs. 6, 8 and 9).

The oldest subunit SUIV-c (Fig. 7d) extends from the basement to horizon A3. Horizon A3 slopes from $4130 \mathrm{~ms}$ TWT in the NE to $6250 \mathrm{~ms}$ TWT in the WSW (Fig. 7e). Generally, the continuous, medium- to high-amplitude horizon A3 lies close (50-200 ms TWT) over the basement (Figs. 6, 8 and 9) and therefore, the topographic high of horizon A3 lies mainly on top of the topographic high of the basement in the NE (Fig. 7a and e). However, horizon A3 terminates against several basement highs and runs horizontally over deeper basement troughs (Figs. 6, 8 and 9). The thickness of subunit SUIV-c thus varies between 0 and $384 \mathrm{~ms}$ TWT and we observe a number of smaller depocenters with a thickness of $>140$ ms TWT distributed over the study area (Fig. 7d). These small depocenters coincide mainly with the topographic lows of 


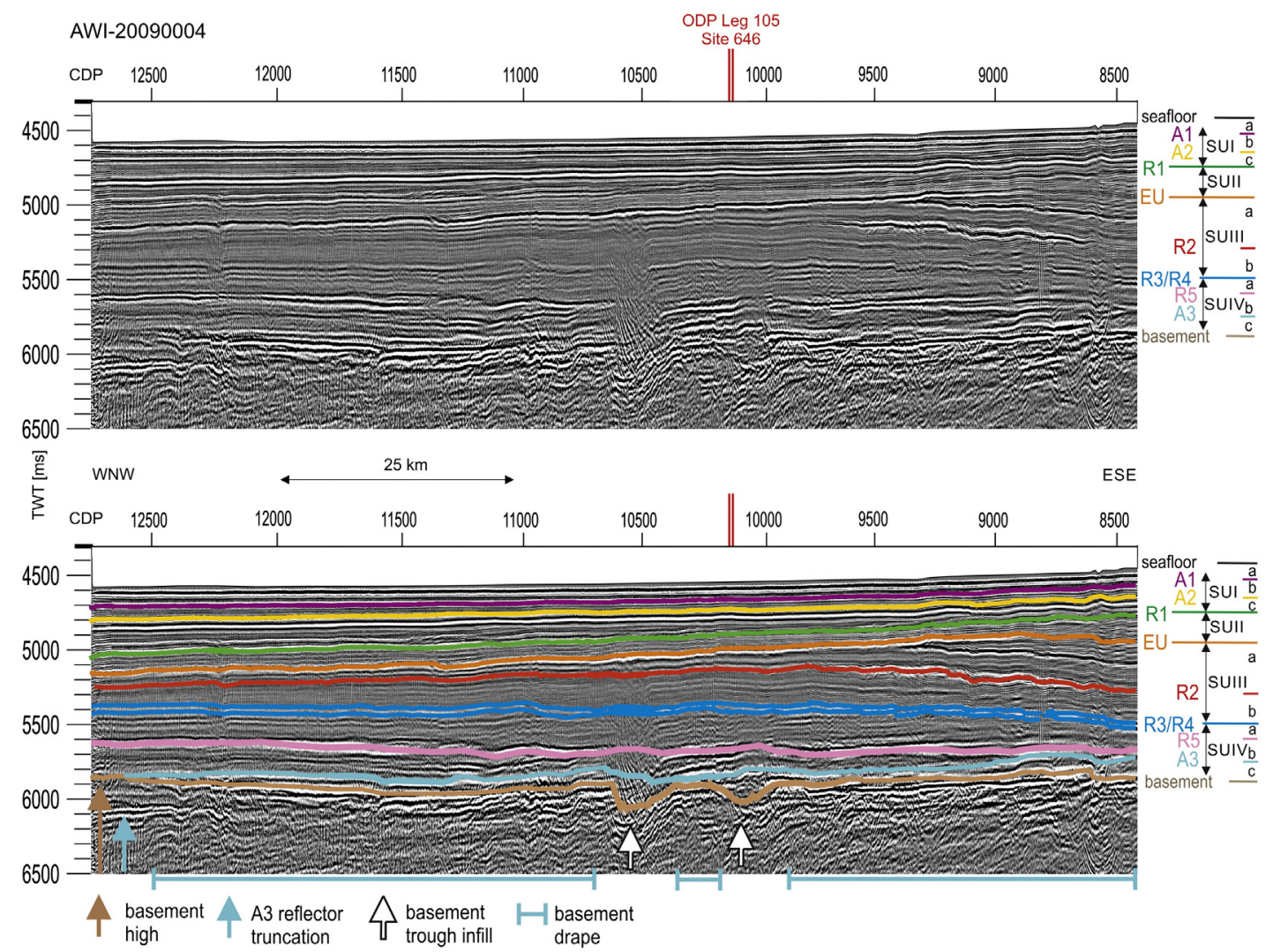

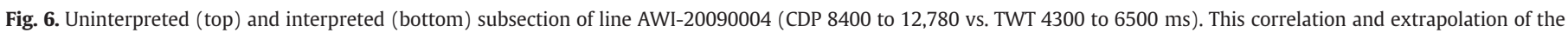

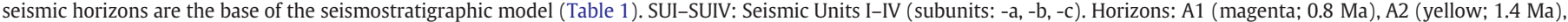

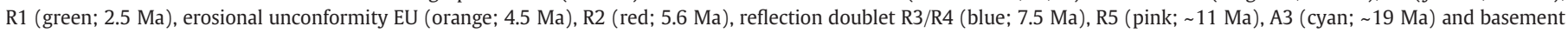
(brown; $50 \mathrm{Ma}$ ).

the basement horizon (Fig. 7a). Apart from the top reflector A3 of medium- to high-amplitude, subunit SUIV-c appears semi-transparent (Figs. 8-9).

Above subunit SUIV-c, subunit SUIV-b (Fig. 7f) extends to its top reflector R5. Horizon R5 slopes from $3900 \mathrm{~ms}$ TWT in the NE to $5950 \mathrm{~ms}$ TWT in the WSW (Fig. 7g). The topographic high of horizon R5 is located in the NE branching towards the SW in the southern central study area (Fig. $7 \mathrm{~g}$ ). In comparison to the basal horizon A3, the topographic high of top reflector R5 is shifted to the east and obliquely elongated to the SW in its shape (Fig. 7e and g). The topographic low of horizon R5 in the west is almost homogenous and lies between 5500 and 6000 ms TWT (Figs. 6 and 7g). In this western part of the study area, the internal low- to medium-amplitude reflections of subunit SUIV-b are parallel to subparallel (Fig. 6). The main depocenter of subunit SUIV-b is found in the SE part of the study area with a maximum sediment thickness of 900 ms TWT (Fig. 7f). Its wavy outline lies at a depth of 435 ms TWT, and it appears plastered onto the southern flank of horizon A3's topographic high (Fig. 7e and f). Here, subunit SUIV-b is lenticularly shaped (Figs. 8-9). The internal reflections of SUIV-b show low-angle downlaps to the basal horizon A3 and diverge towards the east (Figs. 8-9). The low amplitudes of the internal reflections increase towards the medium- to highreflection band near the top (Figs. 8-9). Top horizon R5 lies within this band of higher reflections, and a number of vertical to sub-vertical faults are observed (Figs. 8-9).

The uppermost subunit SUIV-a is bounded by horizon R5 below and horizon doublet R3/R4 at the top. Its thickness varies between 50 and $940 \mathrm{~ms}$ TWT (Fig. 7h). The depocenter of subunit SUIV-a comprises sediments thicker than $430 \mathrm{~ms}$ TWT and is located in the SE part of the study area (Fig. 7h). Two branches extend to the WSW and NW
(Fig. 7h). The depocenter lies on top of the southern flank of reflector R5's topographic high partly extending into the adjacent topographic lows (Fig. $7 \mathrm{~g}$ and $\mathrm{h}$ ). The internal reflections of subunit SUIV-a are of low amplitudes in the center of the unit and of medium- to highamplitude near the top and bottom (Figs. 8-9). Within the depocenter, subunit SUIV-a appears lenticularly shaped, and it comprises diverging internal reflections (Figs. 8-9). Subunit SUIV-a is of almost homogenous thickness elsewhere, and the internal reflections are parallel to subparallel (Fig. 6).

\section{Discussion}

The Miocene unit SUIV has been poorly investigated but is of great interest as the investigation of paleocurrents is fundamental for our present understanding of the oceans climate history. Our key objective in this study was to address the question as to whether or not there are indications for the onset of current-controlled sedimentation of the Eirik Drift before 7.5 Ma. Seismic characteristics typical of currentcontrolled sedimentation and contourite drifts have been described by several authors (e.g. McCave and Tucholke, 1986; Faugères et al., 1999; Stow et al., 2002; Faugères et al., 2008; Nielsen et al., 2008), and key observational criteria are summarized below:

1 Major changes in depositional style from non-current dominated to current dominated regime and vice versa cause high- to moderate amplitude reflections.

2 Initiation of a strong deep current is accompanied by non-deposition/ erosion.

3 Erosional unconformities are characterized by a single continuous high- to moderate amplitude reflector of regional to semi-regional 
extent. Commonly, the onset of deep current-controlled sediment accumulation is marked by a basal unconformity.

4 Internal reflections commonly show low-angle downlap onto these basal erosional unconformities.
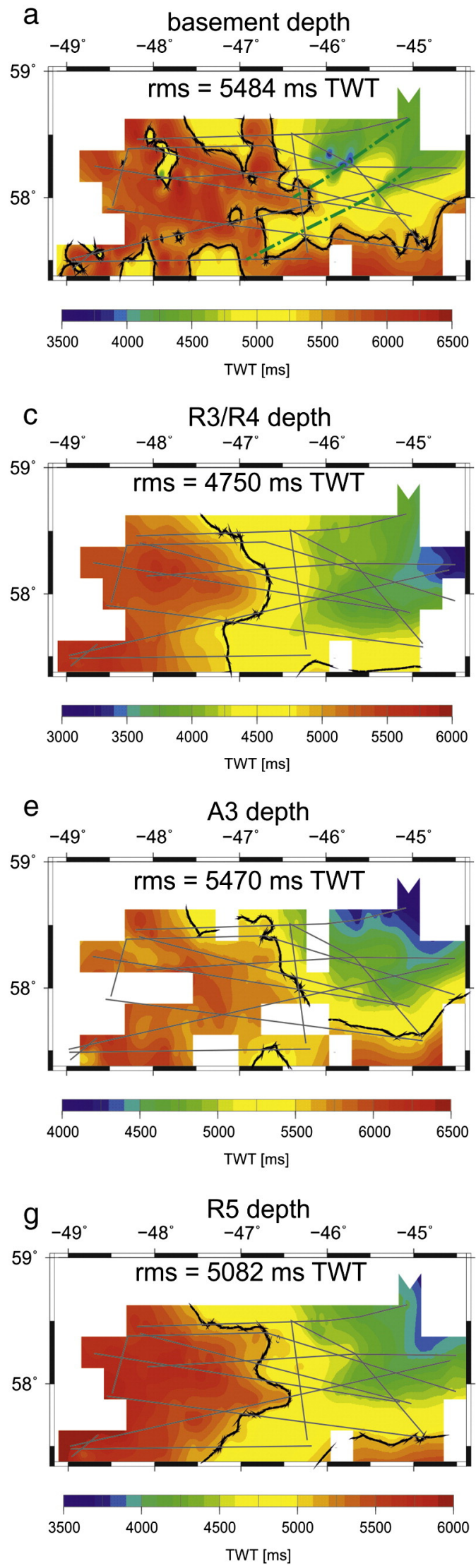
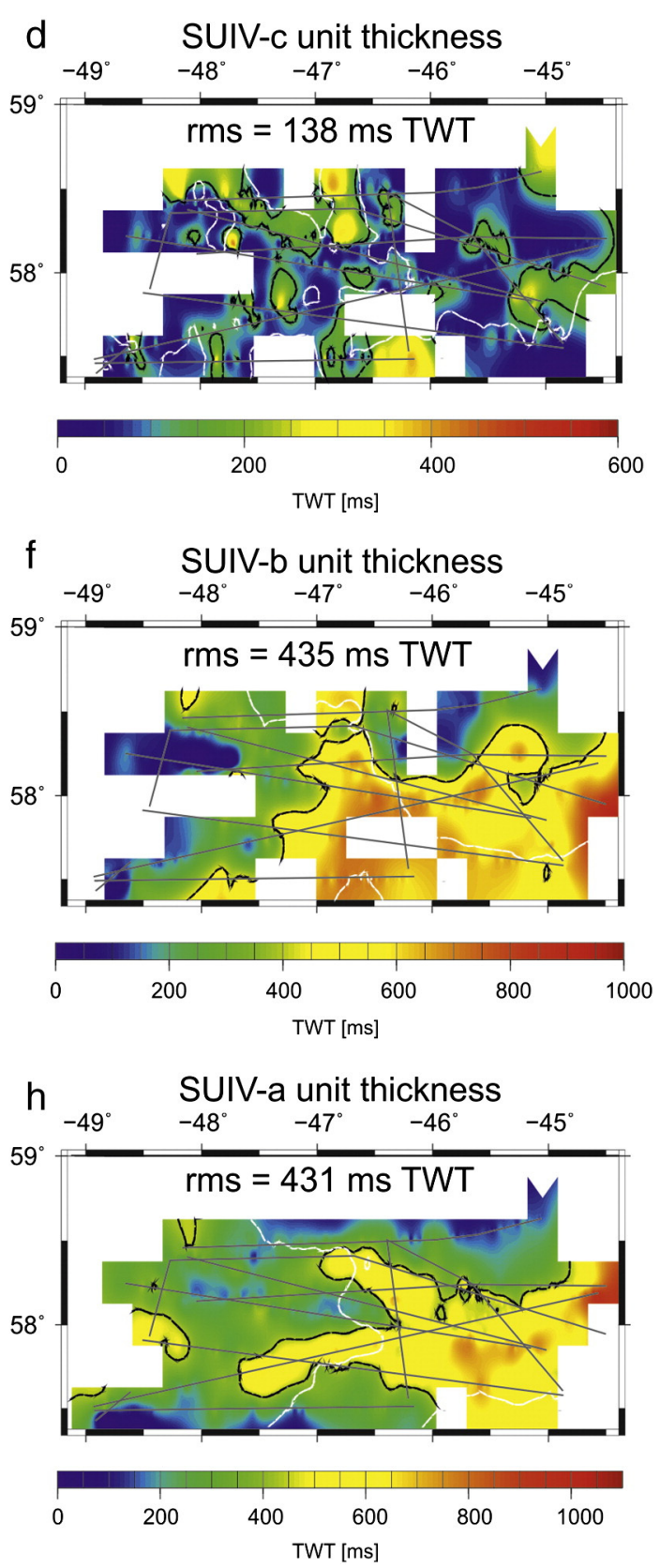

5 An indication for drift deposits is their thickness, which exceeds that of the adjacent sediment cover. However, morphology, location and internal reflection characteristics of thick sediment deposits have to be investigated to distinguish drift deposits from mass-transport deposits.

b

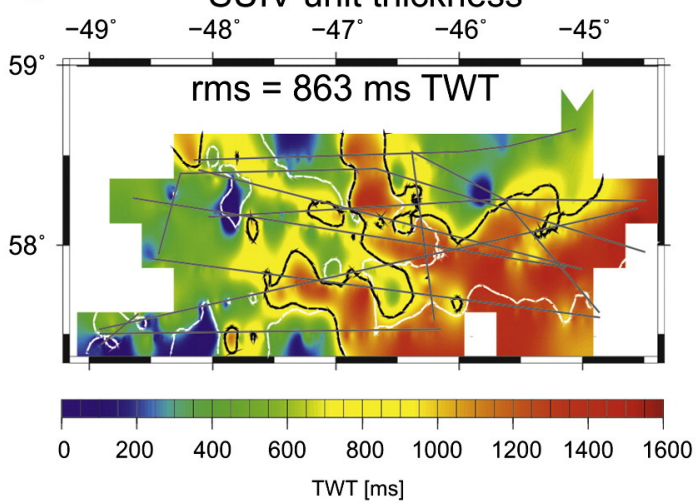




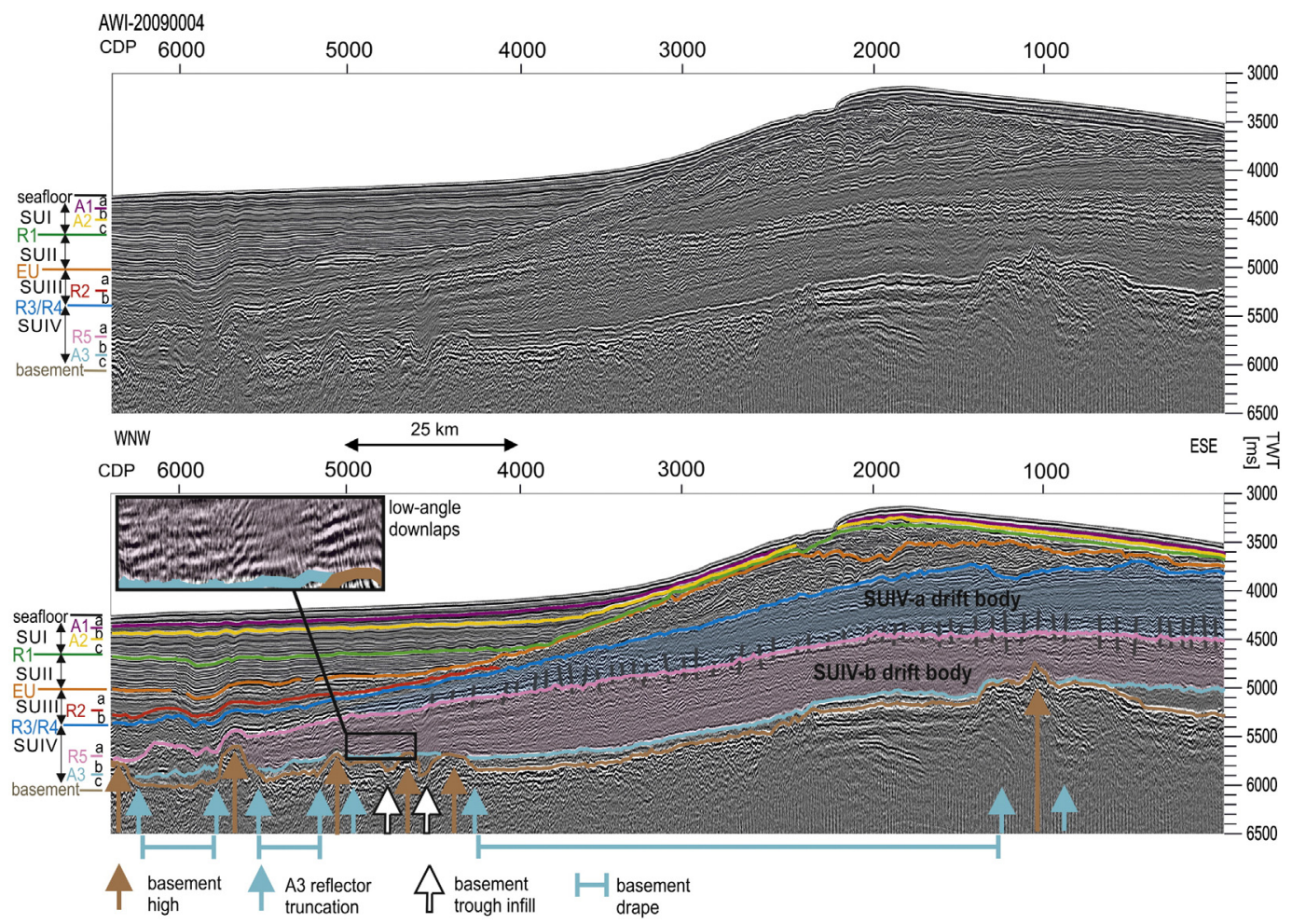

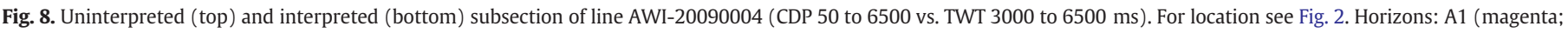

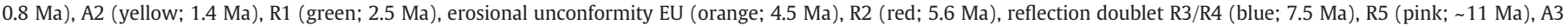
(cyan; $19 \mathrm{Ma}$ ) and basement (brown; 51 Ma). Pink and blue transparent patches highlight drift bodies within subunit SUIV-b and SUIV-a, respectively.

6 Drift deposits are found along-slope in contrast to mass-transport deposits, which are observed in down-slope direction.

7 The stronger mean flow of the deep-current core at the steeper drift flank causes erosion and/or reduced net accumulation.

8 Higher sediment accumulation is found at the comparatively tranquil sides of the deep-current core.

9 The geometries of the internal seismic units are lenticular or sigmoidal shaped, due to the above-mentioned regulations of erosion and accumulation at sediment drifts.

Several different types of sediment drifts can be distinguished and their overall shape and geometry are due to an interplay of different boundary conditions: the location and its topography, the current velocity and variability, the amount and type of sediment available, and the time span at which the deep-current was active. The Eirik Drift is classified as a detached elongated, mounded drift. These are distinctly mounded and elongated in shape.

One of the principal controls on the morphology of a detached elongated, mounded drift appears to be the form of the pre-existing seafloor, which controls and directs the various contour-following branches of the deep current. Elongated detached drifts usually prograde in the direction of the initial flow and their crests are found parallel to the prevailing deep current direction, but progradation can also lead to parts of the drift being elongated almost perpendicular to the margin. This is the case for the Eirik Drift in response to a change to the margin's trend as the intensity of the deep current is commonly related to the steepness of the slope with intensification of the current core at steeper slopes and weaker currents at gentle slopes. For detached elongated drifts in the Northern Hemisphere the higher sediment accumulation is found always to the right of the current core due to Coriolis force. Currents directed oppositely at both drift flanks yield in increased sedimentation at the drift axis. Subsidiary drift crests can be found in the downcurrent flank. Drift deposits are lenticular in shape with the bedding thickening at the drift axis and thinning towards either both drift flanks or the flank where the flow is fastest. At the thinner parts the internal reflections converge while diverging internal reflections are found at the areas of increased accumulation at the drift axis. Thus, the internal reflections describe a uniform pattern of continuous low to medium amplitude reflections that tend to follow the main drift morphology.

By means of the extended stratigraphy assessed at site ODP 646, we identified Miocene unit SUIV and divided it into 3 subunits. We observed that the depocenter of unit SUIV appears attached to the SW flank of the topographic high of the basement (Fig. 7a and b). The thicker sequence at the elevated basement flank compared to the thinner sequence at the basement topographic lows in the west of the study area is a strong indication for deep current controlled deposition (McCave and Tucholke, 1986; Faugères et al., 1999; Stow et al., 2002; Faugères et al., 2008; Nielsen et al., 2008). To confirm the assumption that deep current-controlled sedimentation started during deposition of unit SUIV and to identify its onset, the subunits of unit SUIV are investigated in more detail below.

The oldest subunit SUIV-c overlies basement. Its top horizon A3 onlaps on several basement highs (Figs. 8-9). The small, patch-like

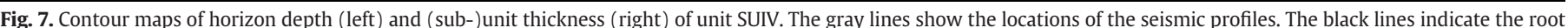

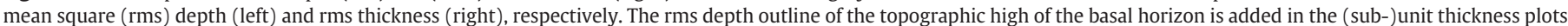

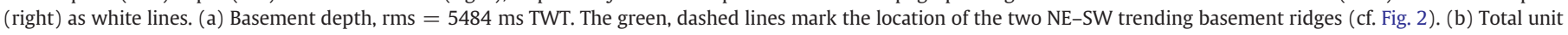

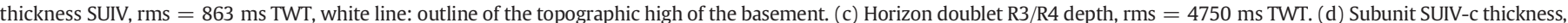

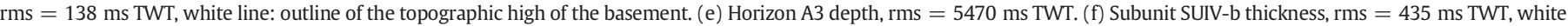

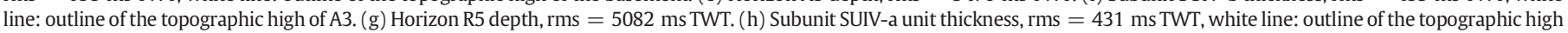
of R5. 


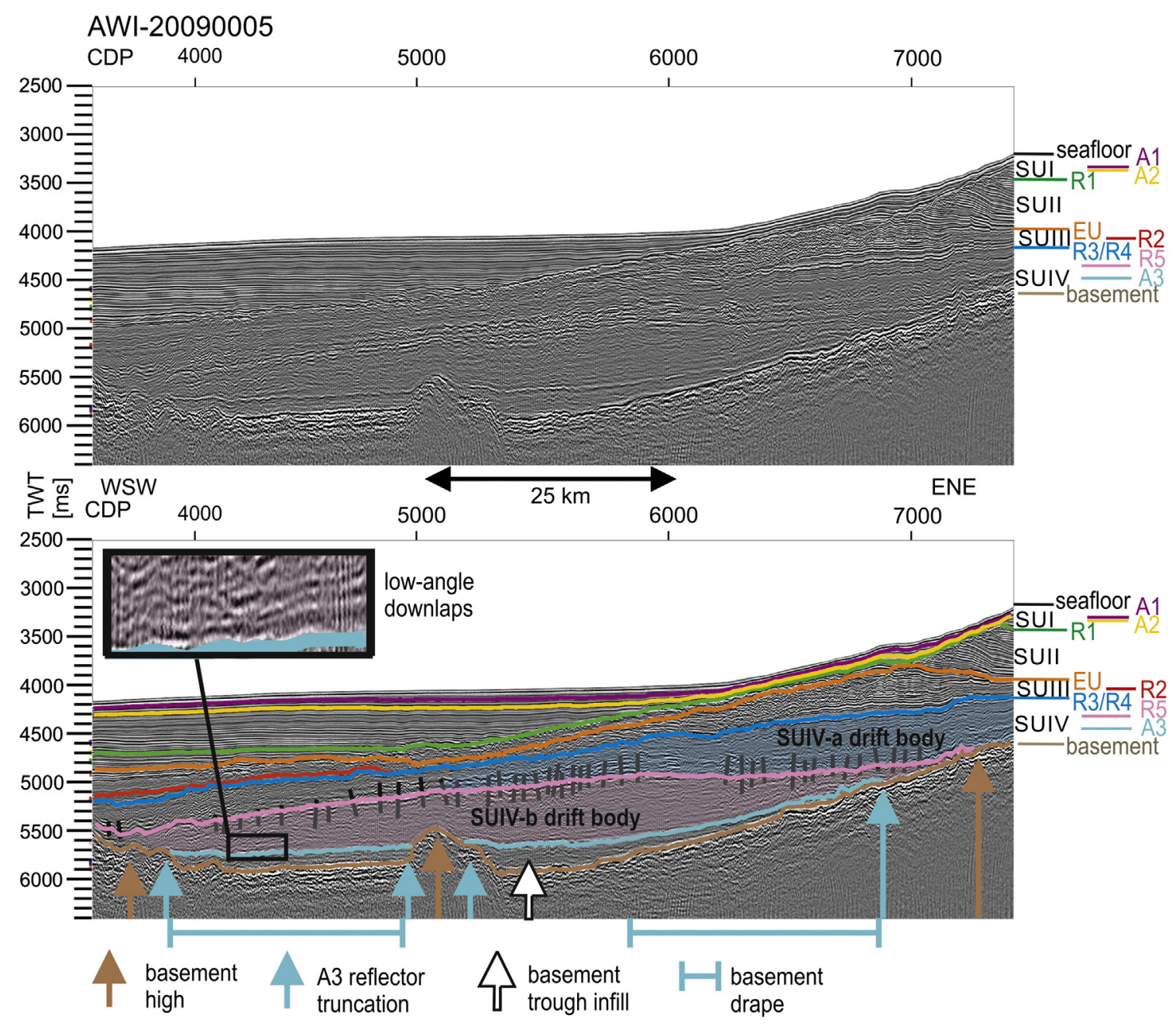

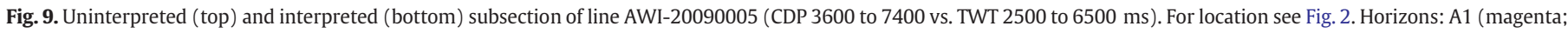

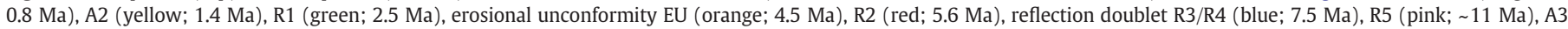
(cyan; $19 \mathrm{Ma}$ ) and basement (brown; $53 \mathrm{Ma}$ ). Pink and blue transparent patches highlight drift bodies within subunit SUIV-b and SUIV-a, respectively.

distributed depocenters of subunit SUIV-c lie mainly in the topographic lows of the basal basement horizon and are interpreted as an infill of the irregular basement topography (Fig. 7a and d). Therefore, the top horizon A3 shows a smoothed morphology compared to the underlying basement horizon (Fig. 7a and e). This points to a drape of the underlying basement reflector during deposition of subunit SUIV-c. The seismic transparency of subunit SUIV-c indicates that the depositional conditions for the sedimentation were tranquil and stable.

In contrast to subunit SUIV-c, the upper subunits SUIV-b and -a show distinct depocenters, which are attached to (SUIV-b; Fig. 7f) or lie on top of (SUIV-a; Fig. 7h) the topographic highs of their basal interfaces (Fig. 7e and g). The development of depocenters at the topographic highs of their basal interfaces indicates that no uniform sedimentation during deposition of subunits SUIV-b and -a occurred. The location of the depocenters at the SE flanks of the topographic highs of the basal interfaces suggests that the main control on the deposition is related to a contour current flowing around the preexisting seafloor contours (Fig. 7e-h). The depocenters are lenticular shaped and comprise diverging internal reflections (Figs. 8-9). This is typical for detached elongated, mounded contourite drifts as the bedding thickens at the drift axis but thins at the drift flanks. This is due to the location of the deep-current core and the effect of Coriolis force (McCave and Tucholke, 1986; Faugères et al., 1999; Stow et al., 2002; Faugères et al., 2008; Nielsen et al., 2008). The thin parts indicate erosion and/or less sedimentation and are interpreted as the locations of the intense deep current cores, while the thicker parts with the diverging internal reflections denote the drift axis with increased sedimentation in the relatively tranquil zones to the right of the stronger deep current core (McCave and Tucholke, 1986; Faugères et al., 1999; Stow et al., 2002; Faugères et al., 2008). Thus, the combination of thickness, location, orientation, shape and internal reflections of the depocenters all suggest that deep-current-controlled sedimentation was responsible for the deposition of subunits SUIV-b and -a. In addition, subunit SUIV-c and the lower part of subunit SUIV-b appear acoustically transparent but their interface horizon A3 is of high amplitude and continuous apart from its interruption due to basement elevations (Figs. 6 and 8-9). This change in reflection characteristics may be due to a change in sediment supply and/or composition or changes in strength and/or location of the deep current system. There is no drilled sedimentary record of the main part of unit SUIV and therefore, changes in sediment composition cannot be confirmed or excluded. Horizon A3 shows the characteristics of a basal unconformity (single, continuous high-amplitude reflectors of regional to subregional extent). These basal unconformities represent strong, initial pulses of deep contour currents, which are often connected with erosional hiatuses (McCave and Tucholke, 1986; Faugères et al., 1999; Stow et al., 2002; Faugères et al., 2008; Nielsen et al., 2008). We observed low-angle downlaps at horizon $\mathrm{A} 3$, which are also typical for erosional unconformities 
(Figs. 8-9) (Faugères et al., 1999; Stow et al., 2002; Nielsen et al., 2008). Therefore, we suggest horizon A3 marks the onset of drift building at the Eirik Drift.

Even though we interpret both subunits SUIV-b and -a as the result of deep-current controlled deposition, there are some differences between these two subunits. The topographic high of the basal horizon A3 has a semicircle appearance in the NE corner of the study area (Fig. 7e). The topographic high develops to a NE-SW directed, elongated slope at horizon R5 (Fig. 7g) and a more ENE-WSW orientated slope at horizon doublet R3/R4 (Fig. 7c). This is interpreted as elongation and progradation of the Eirik Drift towards the WSW. The depocenter of subunit SUIV-b lies in the SE part of the study area attached to the SW flank of the topographic high of its basal interface A3 (Fig. 7e-f). Deep-current cores flow at isobaths and Coriolis force accounts for deposition to the right of the deep-current cores in the Northern Hemisphere. The combination of the basal interface outline and the location of the depocenter of subunit SUIV-b infers a deep-current core at a contour below the rms value of 5470 ms TWT of the basal interface A3 (Fig. 7e-f). It suggests a deep-current core, which flows SW beyond our study area and turns to a NNW directed flow along the western depocenter outline (Fig. 7f). The depocenter of subunit SUIV-a lies mainly on top of its basal horizon R5 (Fig. 7g-h). The branches of the depocenter, which extend to the NW and WSW indicate a meandering, NW directed deep-current core (Fig. 7h) roughly following the undulations of the rms outline of R5's topographic high at $5082 \mathrm{~ms}$ TWT (Fig. 7g). Therefore, we assume that the deep-current core responsible for deposition of subunit SUIV-a lies at shallower depth than before.

The internal reflections of subunit SUIV-b are of low amplitude. The amplitudes increase towards the top horizon R5, which is found within a band of 3-4 high amplitude reflections (Figs. 8-9). Changes in the deep current system and/or of the supplied sediment can create changes in the impedance contrast, which yields higher amplitude reflectors like these. The faults observed within the high-reflection band surrounding R5 bear analogy to diagenetically induced polygonal fault system due to their swarm-like and apparently layer-bound appearance (Cartwright, 2011). However, diagenetic processes and their typical polygonal planform geometry (Cartwright, 2011) cannot be confirmed due to the lack of geological information and seismic 3-D data. Fluids moving within the sediment, possibly initiated by changing sedimentation rates, or varying current strength and directions, may also cause these vertical to sub-vertical small-scale faults. In combination with the observed shifts of the depocenters and the concluded changes in the deep-current core depth from subunit SUIV-b to SUIV-a, we assume a change in deep-current system at horizon R5.

In the following, we try to set the onset of drift building in the correct chronological context, even though we have no direct age control of borehole data. The top reflector doublet R3/R4 of seismic unit SUIV was dated as 7.5 Ma (Arthur et al., 1989) and marks changes in carbonate content (Kaminski et al., 1989). The suggested onset of NCW overflow at the Denmark Strait (DSOW) at $~ 7$ Ma (Bohrmann et al., 1990) might account for these changes. In addition, Kaminski et al. (1989) found evidence for corrosive, southern-sourced bottom water in the lowermost sedimentary record at ODP 646, i.e. below horizon R3/R4 (8.1-8.6 Ma). Hence, it was concluded, that no NCW flow was active at the Eirik Drift prior to formation of reflector doublet R3/R4 at 7.5 Ma (Arthur et al., 1989; Kaminski et al., 1989). Several authors reported a phase of high NCW production from around 12.5 Ma to the Pliocene with minor interruptions around $9 \mathrm{Ma}$ and 7 Ma (Wright and Miller, 1996; Wright, 1998; Poore et al., 2006). These studies link the deep-water circulation in the North Atlantic to the subsidence history of the Greenland-Scotland-Ridge by investigating the Iceland mantle plume activity in combination with carbon and/or oxygen records in sediment cores. We suggest that these short interruptions of the prevailing NCW flow, account for the formation of the reflector doublet R3/R4 and the $9 \mathrm{Ma}$ event to have been responsible for the record of corrosive southern-sourced deep-water at ODP 646 at 8.18.6 Ma. The medium- to high amplitude reflections found below horizon R3/R4 may be also a result of this variability of NCW flow around 9 Ma. Subunit SUIV-a comprises low-amplitude reflections indicating sedimentation under uniform conditions, i.e. no major changes in sediment supply and/or deep-current intensity occurred.

We estimate the age of horizon R5 at 10-12 Ma, which we derived from extrapolation of sedimentation rates at the lower part of ODP 646. This estimate correlates well with the onset of a phase of high NCW production at $\sim 12.5 \mathrm{Ma}$ (Wright and Miller, 1996; Wright, 1998; Poore et al., 2006), a drift accumulation phase generally observed in the northern North Atlantic at $13 \mathrm{Ma}$ (Miller and Tucholke, 1983; Wold, 1994) and the formation of several erosional unconformities in the northern North Atlantic at 10-13 Ma (Wold, 1994; Wright and Miller, 1996). Hatton and Snorri Drift started to develop at around $13 \mathrm{Ma}$ (Wold, 1994). This happened at the same time when the first significant overflows were observed at the Iceland-Faroe-Ridge $\sim 13-11 \mathrm{Ma}$ (Bohrmann et al., 1990). The high reflection band with its swarm-like faults observed in our data (Figs. 8-9) is similar to the widespread occurrence of a hummocky reflection zone above a relatively reflector-free or low-amplitude section at the US Atlantic continental rise (Mountain and Tucholke, 1985; McMaster et al., 1989; Locker and Laine, 1992). These reflection characteristics were identified below reflector Merlin by Mountain and Tucholke (1985), inferred to represent the initialized stabilization of drift deposits in the western North Atlantic 10-12 Ma ago. Horizon G of McMaster et al. (1989) is concordant with reflector Merlin. Geological drilling results in combination with seismic data revealed, that an interval of deep-current erosion at 11.5-12 Ma caused horizon G (Muza and Covington, 1987; McMaster et al., 1989). Locker and Laine (1992) linked their horizon X (10.5 Ma) with reflector Merlin. They stated that the hummocky seismic facies developed as a result of widespread reworking of sediments by deep contour currents as proposed by Mountain and Tucholke (1985). The hydrological event, which caused the formation of horizon Merlin/G/X in the eastern North Atlantic, was synchronous with a sharp rise in sea level (Haq et al., 1987). Based on the similarity of the reflection characteristics of horizon Merlin/G/X and horizon R5, we confirm the suggested date of horizon R5 (10-12 Ma) and the assumption that horizon R5 represents a change in the deep-current system at the Eirik Drift.

Using sedimentation rates determined at ODP 646, horizon A3 appears to be of middle Miocene age. The production of NCW was disabled between 15 and $12.5 \mathrm{Ma}$ due to increased Iceland mantle plume activity and a resulting uplift of the Greenland-Scotland-Ridge (Miller and Tucholke, 1983; Wright and Miller, 1996). The elimination of NCW production during this phase probably yielded much lower sedimentation rates and therefore has to be taken into account in the age estimation for horizon $\mathrm{A} 3$. We therefore suggest that horizon $\mathrm{A} 3$ is more likely of early Miocene age (19-17 Ma), when initiation of strong NCW fluxes (20-19 Ma; Wright and Miller, 1996) formed widespread erosional unconformities in the northern North Atlantic (Table 2) (McCave et al., 1980; Dingle et al., 1982; Miller and Tucholke, 1983; Masson and Kidd, 1986; McCave and Tucholke, 1986; Stoker et al., 2001) and drift accumulation at Bjorn and Gardar Drift started (Miller and Tucholke, 1983; Wright and Miller, 1996). This is in accordance to the development of the deep-water connection through the Faroe Conduit in early Miocene (Stoker et al., 2005) and the opening of the Fram Strait for a deep-water exchange of the Arctic Ocean to the Nordic Seas (Ehlers and Jokat, 2013).

Subunit SUIV-c underlying horizon A3 was deposited in a tranquil environment. The basement is 40-61 Ma in age and therefore 20$40 \mathrm{Ma}$ older than the estimated age of horizon A3. The mean sedimentation rate of subunit SUIV-c would be $<10 \mathrm{~ms}$ TWT/M.y. and significantly decreased compared to the mean sedimentation rates of subunits SUIV-b (70 ms TWT/M.y.) and SUIV-a (120 ms TWT/M.y.). The question arises whether a tranquil environment would account for such low sedimentation rates or whether horizon A3 might represent a sedimentary hiatus. 
Table 2

North Atlantic erosional unconformities of late Early Miocene age.

\begin{tabular}{|c|c|c|c|}
\hline Reflector age & Reflector name & Region & Citation \\
\hline 19-18 Мa & "Challenger" & Porcupine Bank & Dingle et al. (1982) \\
\hline Late Early Miocene & Regional reflector & Faroe-Shetland region & Stoker et al. (2005) \\
\hline Late Early Miocene & “C20" & Rockall Trough & Stoker et al. (2001) \\
\hline $17 \mathrm{Ma}$ & “Green” & Southern Rockall Trough & Mason and Kidd (1986) \\
\hline $17 \mathrm{Ma}$ & “IR" & Gardar Drift & McCave et al. (1980) \\
\hline 17-16 Ма & “R2" & Rockall, Gloria Drift, Baffin Bay & Miller and Tucholke (1983) \\
\hline
\end{tabular}

Due to its reflection characteristics (a single continuous high- to moderate amplitude reflector of regional to semi-regional extent with lowangle downlaps), horizon A3 was identified as the basal unconformity of the drift, which represents strong, initial pulses of deep contour currents. These often are connected with erosional hiatuses. The observed low-angle downlaps at horizon A3 suggest erosion (Figs. 8-9). Therefore, we interpret horizon A3 as a sedimentary hiatus due to erosion at the onset of intense NCW flux. However, as there is no drilled sedimentary record of the main part of unit SUIV, the assumption of a sedimentary hiatus at horizon A3 cannot be confirmed.

\section{Conclusion}

A new set of high-resolution seismic reflection data has been interpreted with respect to the build-up of the Eirik Drift. We have refined the seismostratigraphic concept of Arthur et al. (1989) adding horizons A1 (0.8 Ma), A2 (1.4 Ma) and A3 (17-19 Ma) and dating horizon R5 (10-12 Ma). Our study suggests that the onset of drift building was instigated in the early Miocene (17-19 Ma), which contrasts with the hypotheses by Arthur et al. (1989) and Wold (1994), who inferred a drift build-up after $\sim 4.5 \mathrm{Ma}$ and after $~ 7-$ $8 \mathrm{Ma}$, respectively.

Our proposed history of sedimentation within the Miocene seismic unit SUIV at the Eirik Drift is as follows:

- Until 19-17 Ma sedimentation at the Eirik Drift was not deepcurrent controlled; deposition of subunit SUIV-c took place in a tranquil and stable environment.

- Horizon A3 is identified as the basal erosional unconformity of the Eirik Drift and is dated 19-17 Ma, when initiation of strong NCW fluxes occurred, as is documented in several erosional unconformities and drifts in the northern North Atlantic. Horizon A3 presumably represents also a sedimentary hiatus due to enhanced erosion. This onset of strong NCW fluxes follows the development of the Faroe Conduit in early Miocene (Stoker et al., 2005) and the onset of deepwater exchange at the Fram Strait (Ehlers and Jokat, 2013).

- Onset of drift building is documented by deposition of unit SUIV-b under the influence of strong NCW fluxes, which were inhibited between 15 and $12.5 \mathrm{Ma}$.

- Changes in the deep-current velocity presumably formed the highamplitude reflection-band surrounding horizon R5 at 12-10 Ma along with a renewed onset of NCW flow. At that time ( 13-11 Ma) the first significant overflows at the Iceland-Faroe-Ridge were observed (Bohrmann et al., 1990).

- Drift elongation and progradation to the WSW under the influence of shallower NCW flow is suggested by the sedimentary record of unit SUIV-a.

- Reflection doublet R3/R4 (7.5 Ma) and the medium- to high amplitude reflections found below this horizon are ascribed to the minor interruptions of NCW flow at 7 and 9 Ma. Presumably, the suggested onset of overflows over the Denmark Strait ( $7 \mathrm{Ma}$; Bohrmann et al., 1990 ) is documented by horizon R3.

In this study, we concentrated on the development of the Eirik Drift during the Miocene to show that drift building at the Eirik Drift started much earlier than previously thought. The refined seismostratigraphic concept will be used in further studies to define a model for the development of pathways and intensity of the NCW flow over the Erik Drift during Neogene and Quaternary.

\section{Acknowledgments}

We are grateful for the support of Captain F. von Staa, his officers and crew during RV Maria S. Merian cruise MSM 12/2. The data collection was funded within the core program METEOR/MERIAN provided by the Deutsche Forschungsgemeinschaft (DFG). This work was funded by the DFG under contract No. Ue 49/12-1. We thank C. Campbell, T. Mulder, M. Stoker and one anonymous reviewer, as well as Editor D.J.W. Piper for their helpful comments and guidance.

\section{References}

Arthur, M.A., Srivastava, S.P., Kaminski, M., Jarrard, R.D., Osler, J., 1989. Seismic stratigraphy and history of deep circulation and sediment drift development in Baffin Bay and the Labrador Sea. In: Srivastava, S.P., Arthur, M., Clement, B., et al. (Eds.), Scientific Results. Ocean Drilling Program, College Station, pp. 957-988.

Bohrmann, G., Henrich, R., Thiede, J., 1990. Miocene to Quaternary paleoceanography in the northern North Atlantic: variability in carbonate and biogenic opal accumulation. In: Bleil, U., Thiede, J. (Eds.), Geological History of the Polar Oceans: Arctic versus Antarctic, 308. Springer, Netherlands, pp. 647-675.

Cartwright, J., 2011. Diagenetically induced shear failure of fine-grained sediments and the development of polygonal fault systems. Marine and Petroleum Geology 28, 1593-1610.

Chalmers, J.A., Pulvertaft, T.C.R., 2001. Development of the continental margins of the Labrador Sea - a review. In: Wilson, R.C.L., Whitmarsh, R.B., Froitzheim, N. (Eds.), Non-Volcanic Rifting of the Continental Margins: A Comparison of Evidence from Land and Sea. Geological Society London, pp. 77-105.

Channell, J.E.T., Kanamatsu, T., Sato, T., Stein, R., Alvarez Zarikian, C.A., Malone, M.J., Expedition 303/306 Scientists, 2006. Proceedings of the Integrated Ocean Drilling Program, vol. 303/306. Expeditions Report North Atlantic Climate.

Channell, J.E.T., Sato, T., Kanamatsu, T., Stein, R., Alvarez Zarikian, C.A., 2010. Expedition 303/306 synthesis: North Atlantic climate. In: Channell, J.E.T., Kanamatsu, T., Sato, T., Stein, R., Alvarez Zarikian, C.A., Malone, M.J., Scientists, Expedition (Eds.) Proceedings of the Integrated Ocean Drilling Program. Integrated Ocean Drilling Program, College Station, TX.

Cramer, B.S., Toggweiler, J.R., Wright, J.D., Katz, M.E., Miller, K.G., 2009. Ocean overturning since the Late Cretaceous: inferences from a new benthic foraminiferal isotope compilation. Paleoceanography 24, PA 4216. http://dx.doi.org/10.1029/ 2008PA001683.

Cremer, M., 1989. Texture and microstructure of Neogene-Quaternary sediments, ODP Sites 645 and 646, Baffin Bay and Labrador Sea. In: Srivastava, S.P., Arthur, M. Clement, B., et al. (Eds.), Scientific Results. Ocean Drilling Program, College Station.

Davies, R., Cartright, J., Pike, J., Line, C., 2001. Early Oligocene initiation of North Atlantic Deep Water formation. Nature 410, 917-920.

Dickson, R.R., Brown, J., 1994. The production of North Atlantic Deep Water: sources, rates, and pathways. Journal of Geophysical Research 99, 12319-12341.

Dingle, R.V., Megson, J.B., Scrutton, R.A., 1982. Acoustic stratigraphy of the sedimentary succession west of Porcupine Bank, N.E. Atlantic Ocean: a preliminary account Marine Geology 47, 17-35.

Ehlers, B.-M., Jokat, W., 2013. Paleo-bathymetry of the northern North Atlantic and consequences for the opening of the Fram Strait. Marine Geophysical Research. http://dx.doi.org/10.1007/s11001-013-9165-9.

Expedition 303 Scientists, 2006. Expedition 303 Summary. In: Channell, J.E.T., Kanamatsu, T., Sato, T., Stein, R., Alvarez Zarikian, C.A., Malone, M.J., Expedition Scientists (Eds.), Proc. IODP. Integrated Ocean Drilling Program Management International, College Station, p. 30.

Faugères, J.C., Stow, D.A.V., Imbert, P., Viana, A.R., 1999. Seismic features diagnostic of contourite drifts. Marine Geology 162, 1-38.

Faugères, J.C., Stow, D.A.V., Camerlenghi, M.R.a.A., 2008. Chapter 14 Contourite Drifts: Nature, Evolution and Controls, Developments in Sedimentology. Elsevier, p. 257.

Gibbard, P.L., Head, M.J., Walker, M.J.C., 2010. Formal ratification of the Quaternary System/Period and the Pleistocene Series/Epoch with a base at $2.58 \mathrm{Ma}$. Journal of Quaternary Science 25, 96-102.

Hansen, B., Østerhus, S., 2000. North Atlantic-Nordic Seas exchanges. Progress in Oceanography 45, 109-208. 
Haq, B.U., Hardenbol, J., Vail, P.R., 1987. Chronology of fluctuating sea levels since Triassic. Science 235, 1156-1167.

Hunter, S., Wilkinson, D., Louarn, E., McCave, I.N., Rohling, E., Stow, D.A.V., Bacon, S. 2007a. Deep western boundary current dynamics and associated sedimentation on the Eirik Drift, Southern Greenland Margin. Deep-Sea Research I 54, 2036-2066.

Hunter, S., Wilkinson, D., Stanford, J., Stow, D.A.V., Bacon, S., Akhmetzhanov, A.M. Kenyon, N.H., 2007b. The Eirik Drift: a long-term barometer of North Atlantic deepwater flux south of Cape Farewell, Greenland. In: Viana, A.R., Rebesco, M. (Eds.), Economic and Palaeoceanographic Significance of Contourite Deposits. Geological Society, London, pp. 245-263.

Kaminski, M.A., Gradstein, F.M., Scott, D.B., Mackinnon, K.D., 1989. Neogene benthic foraminifer biostratigraphy and deep-water history of Sites 645, 646, and 647, Baffin Bay and Labrador Sea. In: Srivastava, S.P., Arthur, M., Clement, B., et al. (Eds.), Scientific Results. Ocean Drilling Program, College Station, pp. 731-756.

Le Pichon, X., Hyndman, R.D., Pautot, G., 1971. Geophysical study of the opening of the Labrador Sea. Journal of Geophysical Research 76, 4724-4743.

Locker, S.D., Laine, E.D., 1992. Paleogene-Neogene depositional history of the middle U.S. Atlantic continental rise: mixed turbidite and contourite depositional systems. Marine Geology 103, 137-164.

Masson, D.G., Kidd, R.B., 1986. Revised Tertiary seismic stratigraphy of the southern Rockall Trough. Initial Reports of the Deep Sea Drilling Project 94, 1117-1126.

McCave, I.N., Tucholke, B.E., 1986. Deep current-controlled sedimentation in the Western North Atlantic. In: Vogt, P.R., Tucholke, B.E. (Eds.), The Geology of North America The Western North Atlantic Region. Geological Society of America, Boulder, pp. 451-468.

McCave, I.N., Lonsdale, P.F., Hollister, C.D., Gardner, W.D., 1980. Sediment transport over the Hatton and Gardar contourite drifts. Journal of Sedimentary Research 50, 1049-1062.

McMaster, R.L., Locker, S.D., Laine, E.D., 1989. The early Neogene continental rise off the eastern United States. Marine Geology 87, 137-163.

Miller, K.G., Tucholke, B.E., 1983. Development of Cenozoic Abyssal Circulation south of the Greenland-Scotland Ridge. In: Bott, M.H.P., Saxov, S., Talwani, M., Thiede, J. (Eds.), Structures and Development of the Greenland-Scotland Ridge - New Methods and Concepts. Plenum Press, New York and London, pp. 549-589.

Miller, K.G., Wright, J.D., Katz, M.E., Wade, B.S., Browning, J.V., Cramer, B.S., Rosenthal Y 2009. Climate threshold at the Eocene-Oligocene transition: Antarctic Ice Sheet influence on ocean circulation. In: Koeberl, C., Montanari, A. (Eds.), The Late Eocene Earth - Hothouse, Icehouse, and Impacts: Geological Society of America Special Paper, pp. 169-178.

Mountain, G.S., Tucholke, B.E., 1985. Mesozoic and Cenozoic geology of the U.S. Atlantic continental slope and rise. In: Poag, C.W. (Ed.), Geologic Evolution of the United States Atlantic Margin. Van Nostrand Reinhold Company, New York, pp. 293-341.

Mueller, R.D., Sdrolias, M., Gaina, C., Roest, W.R., 2008. Age, spreading rates, and spreading asymmetry of the world's ocean crust. Geochemistry, Geophysics, Geosystems 9.

Muza, J.P., Covington, J.M., 1987. Neogene calcareous nannofossils from Deep Sea Drilling Project Site 603, lower continental rise, western North Atlantic: biostratigraphy and correlations with magnetic and seismic stratigraphy. In: van Hinte, J.E. Wise Jr., S.W., et al. (Eds.), Initial Reports Deep-Sea Drilling Project, 93, pp. 593-616.

Nielsen, T., Knutz, P.C., Kuijpers, A., Camerlenghi, M.R.a.A, 2008. Chapter 16 Seismic Expression of Contourite Depositional Systems, Developments in Sedimentology. Elsevier, pp. 301-321.
Poore, H.R., Samworth, R., White, N.J., Jones, S.M., McCave, I.N., 2006. Neogene overflow of Northern Component Water at the Greenland-Scotland Ridge. Geochemistry, Geophysics, Geosystems 7 (6), Q06010. http://dx.doi.org/10.1029/2005GC001085.

Ricker, N., 1953. The form and laws of propagation of seismic wavelets. Geophysics 18 , $10-40$.

Schmitz Jr., W.J., 1996. On the World Ocean Circulation: Volume I Some Global Features/North Atlantic Circulation, Technical Report. Woods Hole Oceanographic Institution, Woods Hole, MA.

Shipboard Scientific Party, 2005. Ice sheet-ocean atmosphere interactions on millennial timescales during the late Neogene-Quaternary using a paleointensity-assisted chronology for the North Atlantic. IODP Expedition 303 Preliminary Report.

Shipboard Scientific Party, 1987a. Site 646. In: Srivastava, S.P., Arthur, M., Clement, B., et al. (Eds.), Init. Repts. Ocean Drilling Program, College Station, pp. 419-674.

Shipboard Scientific Party, 1987b. Explanatory Notes: ODP Leg 105, Baffin Bay and Labrador Sea. In: Srivastava, S.P., Arthur, M., Clement, B., et al. (Eds.), Init. Repts. Ocean Drilling Program, College Station, pp. 21-41.

Smith, W.H.S., Sandwell, D.T., 1997. Global sea floor topography from satellite altimetry and ship depth soundings. Science 277, 1956-1962.

Srivastava, S.P., Arthur, M.A., 1989. Tectonic evolution of the Labrador Sea and Baffin Bay: constraints imposed by regional geophysics and drilling results from Leg 105. In: Srivastava, S.P., Arthur, M., Clement, B., et al. (Eds.), Scientific Results. Ocean Drilling Program, College Station, pp. 989-1009.

Srivastava, S.P., Roest, W.R., 1999. Extent of oceanic crust in the Labrador Sea. Marine and Petroleum Geology 16, 65-84

Srivastava, S.P., Arthur, M.A., Clement, B., et al. (Eds.), 1989. Proceedings ODP, Scientific Results, 105. ODP (Ocean Drilling Program), College Station, TX.

Stoker, M.S., van Weering, T.C.E., Svaerdborg, T., 2001. A mid- to late Cenozoic tectostratigraphic framework for the Rockall Trough. In: Shannon, P.M., Haughton, P., Corcoran, D. (Eds.), The Petroleum Exploration of Ireland's Offshore Basins: Geological Society, London, Special Publication, 188, pp. 411-438.

Stoker, M.S., Hoult, R.J., Nielsen, T., Hjelstuen, B.O., Laberg, J.S., Shannon, P.M., Praeg, D., Mathiesen, A., van Weering, T.C.E., McDonnell, A., 2005. Sedimentary and oceanographic responses to early Neogene compression on the NW European margin. Marine and Petroleum Geology 22, 1031-1044.

Stow, D.A.V., Faugères, J.-C., Viana, A., Gonthier, E., 1998. Fossil contourites: a critical review. Sedimentary Geology 115, 3-31.

Stow, D.A.V., Faugères, J.-C., Howe, J.A., Pudsey, C.J., Viana, A.R., 2002. Bottom currents, contourites and deep-sea sediment drifts: current state-of-the-art. In: Stow, D.A.V., Pudsey, C.J., Howe, J.A., Faugeres, J.-C., Viana, A.R. (Eds.), Deep-Water Contourite Systems: Modern Drifts and Ancient Series. Geological Society of London, London, pp. 7-20.

Wildeboer Schut, E., Uenzelmann-Neben, G., 2006. Tying seismic data to geologic information from core data: an example from ODP Leg 177. Geo-Marine Letters 26, 235-248.

Wold, C.N., 1994. Cenozoic sediment accumulation on drifts in the northern North Atlantic. Paleoceanography 9, 917-941.

Wright, J.D., 1998. Role of the Greenland-Scotland Ridge in Neogene climate changes. In: Crowley, T.J., Burke, K. (Eds.), Tectonic Boundary Conditions for Climate Reconstructions. Oxford University Press, Oxford, pp. 192-211.

Wright, J.D., Miller, K.G., 1996. Control of North Atlantic deep water circulation by the Greenland-Scotland Ridge. Paleoceanography 11, 157-170.

Yilmaz, Ö., 2001. Seismic Data Analysis. Society of Exploration Geophysicists, Tulsa. 